\title{
Validation of meteorological and ground-level ozone WRF-CHIMERE simulations in a mountainous grapevine growing area for phytotoxic risk assessment
}

\author{
D. Blanco-Ward ${ }^{\text {a, }}$, A. Rocha ${ }^{\mathrm{b}}$, C. Viceto ${ }^{\mathrm{b}}$, A.C. Ribeiro ${ }^{\mathrm{c}}$, M. Feliciano ${ }^{\mathrm{c}}$, E. Paoletti $^{\mathrm{d}}$, A. \\ I. Miranda ${ }^{\mathrm{a}}$ \\ ${ }^{\text {a }}$ Centre for Environment and Marine Studies (CESAM) and Department of Environment and Planning (DAO), University of Aveiro, 3810-193, Aveiro, Portugal \\ ${ }^{\mathrm{b}}$ CESAM and Physics Department, University of Aveiro, 3810-193, Aveiro, Portugal \\ c Centro de Investigação de Montanha (CIMO), Instituto Politécnico de Bragança, Campus de Santa Apolónia, 5300-253, Bragança, Portugal \\ ${ }^{\mathrm{d}}$ Research Institute on Terrestrial Ecosystems, National Research Council, Via Madonna Del Piano 10, 50019, Sesto Fiorentino, Florence, Italy
}

\section{H I G H L I G H T S}

- Meteorological and ground-level O3 patterns were successfully replicated in Mediterranean complex terrain by RCM.

- Grapevine O3 stomatal uptake simulations were closer to those present under less water limited conditions.

- Current ground-level O3 can already pose a potential threat for a wine producing area such as the Douro Region in Portugal.

- Ground-level O3 extremes should also be considered along heatwaves and drought as compromising factors for the grapevine.

\section{A R T I C L E I N F O}

\section{Keywords:}

Ozone phytotoxicity

AOT40

POD

Grapevine

Mountainous terrains

Modelling validation

Mediterranean conditions

\section{G R A P H I C A L A B S T R A C T}
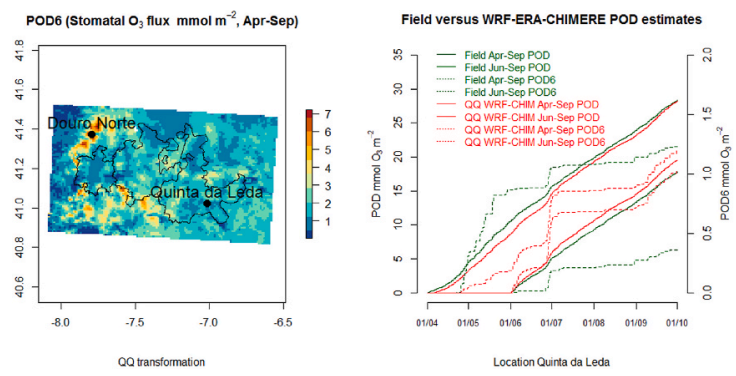

\begin{abstract}
A B S T R A C T
Ozone is the most damaging phytotoxic air pollutant to crop yield quantity and quality. This study presents the validation of a simulation with the WRF-CHIMERE modelling system in order to assess the risk of phytotoxicity by tropospheric ozone for an important and characteristic Mediterranean crop, i.e. the grapevine. The study region was the Douro wine region in Portugal, which is characterized by a rugged relief and a Mediterranean climate. The simulation covered a reference grapevine growing season in the Northern Hemisphere (from April to September 2017), during which a particular measuring campaign was also carried out. The validation of the meteorological simulations on a daily and hourly time resolution was performed based on data from three weather stations, namely on temperature, global solar radiation, relative humidity, wind speed and direction values. The ozone phytotoxicity was assessed with data from two measuring stations. A specific grapevine growth parameter based on monitored phenological observations was introduced for ozone stomatal uptake assessment. Concerning meteorology, validation statistics were acceptable and within the range of what has been found in other regional climate modelling simulations. Ground-level ozone-based values were calculated for a better assessment of the phytotoxic risk, in particular cumulative standards for vegetation protection. Stomatal flux
\end{abstract}

\footnotetext{
* Corresponding author. Centre for Environment and Marine Studies (CESAM) and Department of Environment and Planning, University of Aveiro, 3810-193, Aveiro, Portugal.

E-mail address: dblancoward@ua.pt (D. Blanco-Ward).
} 
estimates were within the range of those measured for the local cultivars in the field campaign when there was not severe water stress limitation. Both field and statistically adjusted model values indicate that considerable areas in the Demarcated Douro Region of Portugal can exceed the critical exposure values for vegetation according to current European legislation standards. Moreover, measured and simulated results indicate an ozone impact on grapevine yield and quality in the target region because the exposure- and flux-based indices exceed the criteria based on current open-top-chamber experimental knowledge.

\section{Introduction}

Ozone $\left(\mathrm{O}_{3}\right)$ stands out as the tropospheric pollutant with greatest phytotoxic effect on crops, pastures and forests (Ainsworth et al., 2012; Booker et al., 2009; Li et al., 2017). Yield losses have been estimated to range between 5 and $20 \%$ for important crops, such as wheat, rice and legumes, and they can reach greater figures depending on the sensitivities of the different cultivars (Avnery et al., 2011; Feng et al., 2019; Van Dingenen et al., 2009). It is expected that background levels of tropospheric $\mathrm{O}_{3}$ will continue to increase globally in relation to the increasing industrialization of developing countries and intercontinental transport. However, the effects of emission reduction policies, such as the reduction of maximum $\mathrm{O}_{3}$ peak levels or leveling off or even declines of long-term trends have also been observed in Europe, North America and Japan (Oltmans et al., 2013; Paoletti et al., 2014; Sicard et al., 2013; The Royal Society, 2008). Concerning $\mathrm{O}_{3}$ metrics of relevance for vegetation, the highest 2010-2014 $\mathrm{O}_{3}$ levels were found in the mid-latitudes of the Northern Hemisphere including southern United States of America, the Mediterranean basin, northern India, north, north-west and east China, the Republic of Korea, and Japan (Mills et al., 2018). Moreover, the Mediterranean area is susceptible to a greater exposure to environmental $\mathrm{O}_{3}$ with a higher incidence of warm summers and heat waves (Jacob and Winner, 2009; Katragkou et al., 2011; Meleux et al., 2007). Considering projected surface $\mathrm{O}_{3}$ concentrations simulated by six global atmospheric chemistry transport models on the basis of a representative concentration scenario (RCP8.5), Sicard et al. (2017) found that many areas of the Northern Hemisphere (e.g. North America, Greenland, Europe, southern Asia, northeastern China) would undergo an increase of $\mathrm{O}_{3}$ levels and risk of $\mathrm{O}_{3}$ injury for vegetation in association with an increase in methane emissions, global warming and weakened nitric oxide titration. These results are in line with those found under RCP8.5 by Fortems-Cheiney et al. (2017) for Europe.

The grapevine is the crop where the phytotoxic effects of $\mathrm{O}_{3}$ were first noticed (Richards et al., 1959). Although it is not a food security crop, such as wheat, rice, soybean, maize or potato, it has immense cultural, economic and ecological importance within the Mediterranean basin, besides being the fruit crop with the largest acreage and highest economic value globally (Ponti et al., 2018). Since the early observations from the fifties, there is nowadays a greater knowledge and awareness of the effects of $\mathrm{O}_{3}$ on grapevine and its defense mechanisms (Blanco-Ward et al., 2021; Pellegrini et al., 2015; Valletta et al., 2016), but there are wide gaps that prevent to relate the exposure or stomatal uptake of $\mathrm{O}_{3}$ with grapevine yield and quality (CLRTAP, 2017a; Mills et al., 2006).

There is already a good number of studies in relation with climate change as a potential threat to wine production and typicity (e.g. BlancoWard et al., 2019Blanco-Ward et al., 2019; Fraga et al., 2016; Mira de Orduña, 2010; Van Leeuwen and Darriet, 2016), but there is still a lack of studies addressing the potential effects of changes in the meteorological fields, drought or carbon dioxide atmospheric enrichment in relation to surface $\mathrm{O}_{3}$ for this crop. An example where the potential phytotoxic effect of $\mathrm{O}_{3}$ in the context of climate change has been considered is the work of Miranda et al. (2020) in the Demarcated Douro Region (DDR) of Portugal suggesting that the tropospheric $\mathrm{O}_{3}$ levels in the future would influence the quality and productivity of wine in the region. However, further refinement is needed in order to not rely solely on $\mathrm{O}_{3}$ exposure, but also on the stomatal $\mathrm{O}_{3}$ uptake by the grapevine in the study area.

A modelling approach can be very useful when assessing the risks of climate change on crops, but it is necessary to validate simulations with data from meteorological and air quality station measuring networks, as well as data of the physiological behavior of the crops. The purpose of this paper is to evaluate high resolution $(1 \mathrm{~km} \times 1 \mathrm{~km})$ meteorological and ground-level $\mathrm{O}_{3}$ simulations aimed at performing a crop risk assessment for grapevine, based on current $\mathrm{O}_{3}$ standards for vegetation protection, including the phytotoxic $\mathrm{O}_{3}$ dose (POD) i.e. the accumulated stomatal $\mathrm{O}_{3}$ uptake over the growing season (CLRTAP, 2017b). To accomplish this objective, the following research questions are addressed. Can a chemical transport modelling (CTM) system successfully replicate the meteorological and ground level ozone patterns in a complex terrain under Mediterranean climate conditions such as those present in the Douro wine region in Portugal? To which extend the range of simulated stomatal fluxes adequately represents those of the grapevine cultivars present in the study area to estimate POD? Can current ground-level $\mathrm{O}_{3}$ be related to any potential risk for a renowned wine producing region such as the Douro river valley in Portugal?

\section{Study area}

The Portuguese Douro Demarcated Region (DDR) crosses the two banks of the Douro River from the border with Spain until halfway through its course. The Douro valley stretches along $90 \mathrm{~km}$ in the westeast direction and along $50 \mathrm{~km}$ in the north-south direction (Fig. 1). The westernmost region is located $70 \mathrm{~km}$ away from the Atlantic Ocean. The landscape is characterized by mountainous terrain, rising above the Douro river and its tributaries, with moderate to steep slopes and different expositions. The average elevation in the region is $443 \mathrm{~m}$, but varies from about $40 \mathrm{~m}$ to a maximum of more than $1400 \mathrm{~m}$. The Region covers about 250 thousand hectares with vineyard areas representing 43480 ha, $17.4 \%$ of the total area. It is divided into three sub-regions: Baixo Corgo with the smaller area (45000 ha), Cima Corgo, with intermediate extension (95000 ha), and Douro Superior with the greater extension (110000 ha). The vineyard area for these subregions is 13368, 20270 and 9842 ha, respectively (Instituto dos Vinhos do Douro e Porto, 2017).

The DDR presents a warm temperate climate (Köppen Csb), with average annual temperatures, for the period $1980-2009$, of $15.4^{\circ} \mathrm{C}$, mean minimum daily temperature (Tmin) in the coldest month of $2.7^{\circ} \mathrm{C}$ and average of the maximum daily temperature (Tmax) in the hottest month of $32.1{ }^{\circ} \mathrm{C}$. The mean rainfall of the driest month (July) is only $11.2 \mathrm{~mm}$, but highly variable rainfall events are concentrated in the winter months. The region is protected from the humid and cold winds of the Atlantic Ocean by two mountain ranges, Marão and Montemuro, which are located on its western border. The temperature increases and precipitation decreases from west to east. The westernmost sub-region of the Douro Valley (Baixo Corgo) is closer to the Atlantic Ocean and therefore more affected by the moist sea winds. The easternmost subregions are further away from the Atlantic Ocean, thus having a more continental climate influence. Low precipitation values, together with high temperatures and high radiation exposure, give rise to intense water and thermal stresses, particularly in the Cima Corgo and Douro Superior subregions (Jones and Alves, 2012). 


\section{Data sources and calculations}

Modelled and measured meteorological and $\mathrm{O}_{3}$ values were compared and analyzed using selected statistical quality indicators for a field campaign period from April to September 2017. Moreover, $\mathrm{O}_{3}$ standards for vegetation were calculated and assessed.

\subsection{Field campaign data}

The meteorological data were obtained from two meteorological stations (Pinhão and Vila Real) from the Portuguese Institute for the Sea and the Atmosphere (IPMA) and one meteorological station (Quinta da Leda) from a wine company in Portugal, Sogrape Vinhos. The Pinhão $(130 \mathrm{~m})$ and Quinta da Leda $(228 \mathrm{~m})$ are located in the Douro valley under Mediterranean climate conditions whereas Vila Real (561 m) represents plateau conditions where there is a stronger sub-Atlantic oceanic influence (Ribeiro, 2000). Two observational sites for ambient $\mathrm{O}_{3}$ were also available: the Douro Norte station $(1086 \mathrm{~m})$ belonging to the Portuguese Environmental Agency and the Quinta da Leda station $(228 \mathrm{~m})$, which was made operative specifically in the scope of the DOUROZONE project, and from April to September 2017. The location of the meteorological and $\mathrm{O}_{3}$ monitoring stations can be observed in Fig. 1 (b, c, d, e). The April to September growing season length is commonly taken as a valid reference grapevine growing season in the Northern Hemisphere (Tonietto and Carbonneau, 2004) and is used concerning $\mathrm{O}_{3}$ risk assessment for perennial crops and deciduous trees (Mills et al., 2018).

Along the same period, in Quinta da Leda, the phenological development of two grapevine cultivars characteristic of the DDR, 'Touriga Franca' and 'Touriga Nacional', was monitored once per week according to the Biologische Bundesanstalt, Bundessortenamt und CHemische Industrie (BBCH) phenological scale. Six representative plants per cultivar were chosen. For each of the two cultivars, it was considered that certain phenological stage had been reached when at least two of the six plants manifested it in a dominant way whereas the remaining ones had also started to display it. Table 1 shows the dates of the main phenological stages considered for those cultivars at Quinta da Leda in 2017. No major differences were found in the phenological development of the two cultivars although there was more variation in the first phenological stages.

a)
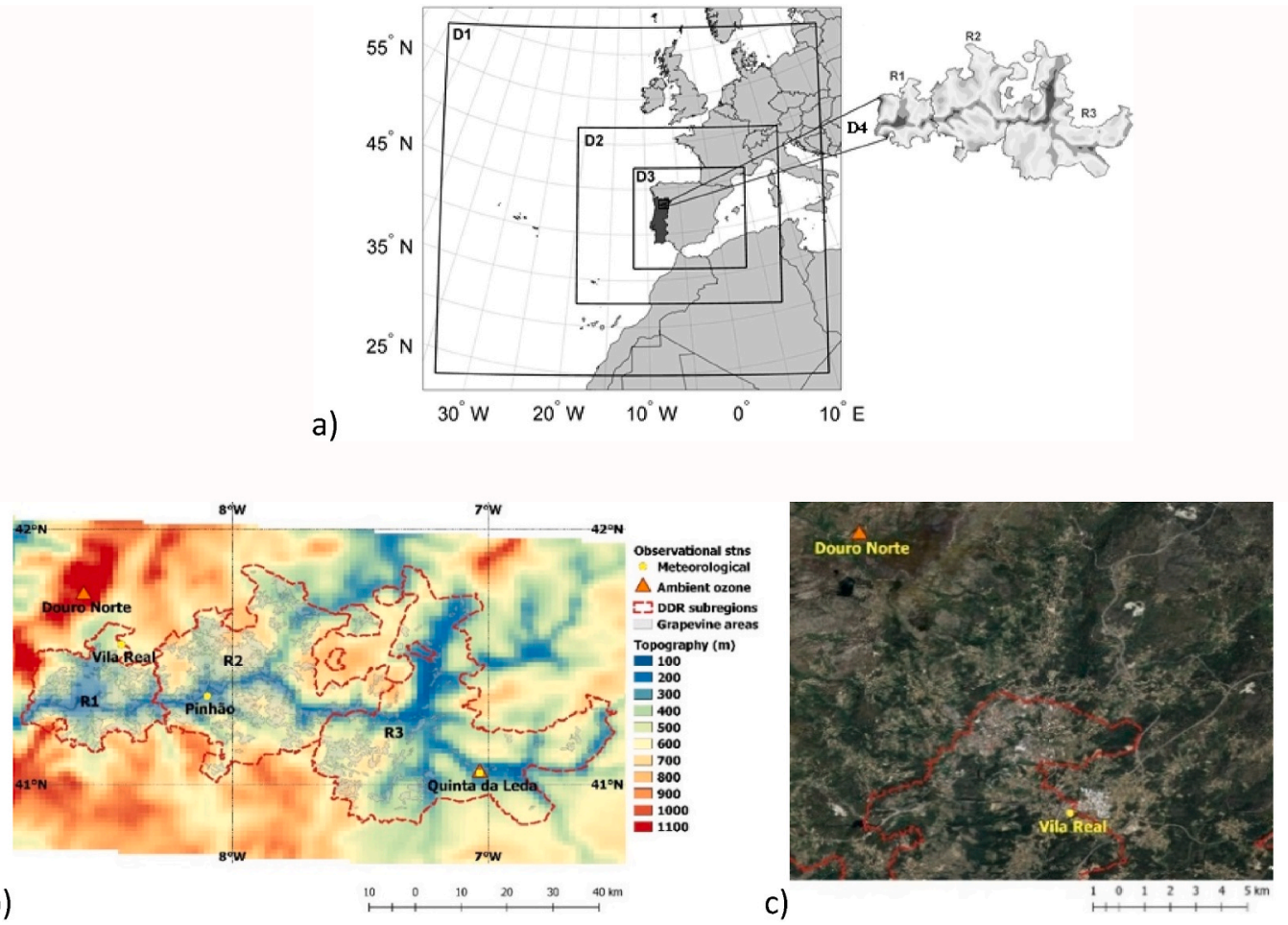

b)

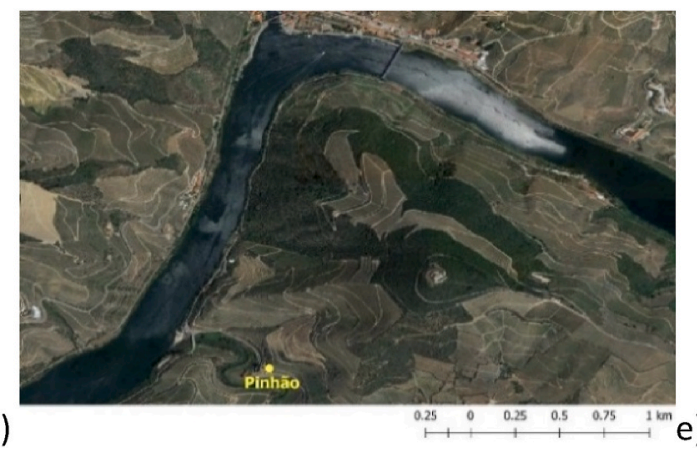

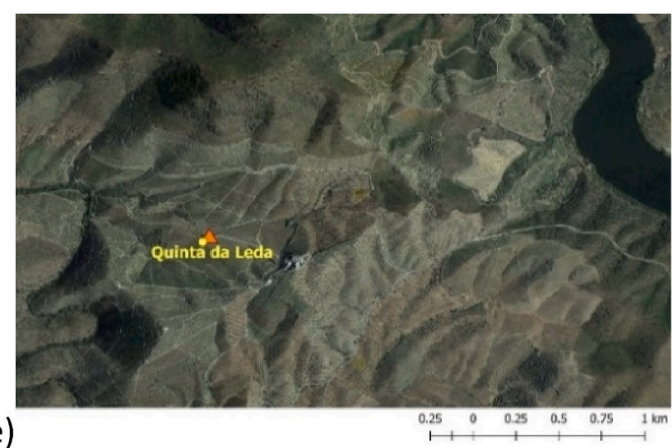

e)

Fig. 1. a) Nested modelling domains and location of the Douro Demarcated Region (DDR) in northern Portugal. b) Subregions "Baixo Corgo" (R1), "Cima Corgo" (R2) and "Douro Superior" (R3), along vineyard areas and observational sites. c, d, e) Detail of observational sites. 
Table 1

Dates of main phenological stages for two characteristic grapevine cultivars of the DDR as observed at Quinta da Leda through the 2017 field campaign.

\begin{tabular}{|c|c|c|c|}
\hline $\begin{array}{l}\text { BBCH Phenological } \\
\text { stage }\end{array}$ & Date & cv. Touriga Nacional & cv. Touriga Franca \\
\hline Bud burst & $\begin{array}{l}29 / 03 / \\
17\end{array}$ & 3 (9D), 3 (9I) & 4 (9D), 2 (11D) \\
\hline $\begin{array}{l}\text { Beginning of } \\
\text { flowering }\end{array}$ & $\begin{array}{l}03 / 05 / \\
17\end{array}$ & $\begin{array}{l}1(61 D), 3(60 D), 2 \\
(60 I)\end{array}$ & $\begin{array}{l}1 \text { (61D), } 1 \text { (60D), } 4 \\
(60 I)\end{array}$ \\
\hline Beginning of ripening & $\begin{array}{l}05 / 07 / \\
17\end{array}$ & $6(81 D)$ & $6(81 D)$ \\
\hline $\begin{array}{l}\text { Berries ripe for } \\
\text { harvest }\end{array}$ & $\begin{array}{l}23 / 08 / \\
17\end{array}$ & 6 (89D) & 6 (89D) \\
\hline Beginning of leaf-fall & $\begin{array}{l}27 / 09 / \\
17\end{array}$ & 6 (93D) & $6(93 D)$ \\
\hline
\end{tabular}

Note: the phenological summary for each of the cultivars is expressed as the number of plants that have reached a given $\mathrm{BBCH}$ phenological stage. $\mathrm{BBCH}$ code 9 stands for bud burst, 11 for first leaf unfolded, 60 first flower hoods detached from the receptacle, $6110 \%$ of flower hoods fallen, 81 beginning of ripening: berries begin to develop variety-specific colour, 89 berries ripe for harvest, 93 beginning of leaf-fall. For this specific monitoring, letters D and I are used to indicate a dominant or incipient stage manifestation. For instance, 3 (9D), 3(9I) corresponds with 3 grapevine plants reaching bud burst (BBCH code 9) as a dominant stage and other 3 grapevine plants which start to manifest that phenological stage.

\subsection{Model simulations}

The Weather Research and Forecasting (WRF) model is a mesoscale numerical weather prediction system, which can be used in a wide range of applications across scales from tens to thousands of kilometres. A detailed description of the model is provided by Skamarock et al. (2008), and further information on parameterizations, specifically suited for the Iberian Peninsula, is in Marta-Almeida et al. (2016). The WRF model was used initially as a dynamical downscaling tool to obtain regional meteorological information from the ERA-Interim reanalysis dataset. The WRF high-resolution climate simulations were implemented for four nested domains with increasing horizontal resolution, namely 81 (D1), 27 (D2), 9 (D3), and $1 \mathrm{~km}$ (D4) (Fig. 1a). The WRF modelled period analyzed for meteorological validation purposes consisted of hourly results from April 1st to September 30th.

The chemical and atmospheric transport model CHIMERE (Menut et al., 2013) was used to estimate ground-level $\mathrm{O}_{3}$ exposure while the dose of $\mathrm{O}_{3}$ entering the plant was calculated based on the dry deposition of $\mathrm{O}_{3}$ for stomatal exchange (DO3SE) model of the European Monitoring and Evaluation Programme for long-range transmission of air pollutants (EMEP) (Emberson et al., 2000b), updated according to the last parametrizations available for grapevine (CLRTAP, 2017c; Emberson et al., 2005). WRF simulations results were used as meteorological inputs for CHIMERE together with anthropogenic pollutants emission data from the emission database of EMEP, which were pre-processed for the four domain configurations. Biogenic emissions were computed using the global Model of Emissions of Gases and Aerosols from Nature (MEGAN). Land use types needed by CHIMERE to calculate biogenic emissions, as well as other processes such as deposition, were derived from the U.S. Geological Survey (USGS) $1 \mathrm{~km}$ resolution land cover database. The CHIMERE chemical mechanism is based on the MELCHIOR scheme (Mailler et al., 2016). Hourly $\mathrm{O}_{3}$ simulated values were obtained for the field campaign period - April 1st to September 30th.

\subsection{Selected variables and $\mathrm{O}_{3}$ standards}

High ambient $\mathrm{O}_{3}$ concentrations do not always correspond to high stomatal $\mathrm{O}_{3}$ fluxes as stomatal closure is induced by low solar radiation and high vapour pressure deficit. Wind also affects laminar resistance to ozone flux into plant leaves. Therefore, the following variables selected for the evaluation of the meteorological simulated values from April to
September 2017, were considered: daily maximum temperature (Tmax), hourly mean temperature (Tmean), daily maximum global solar radiation (Radmax), hourly mean global solar radiation ( $R a d)$, daily minimum relative humidity ( $R H \mathrm{~min})$, hourly mean relative humidity $(R H)$, hourly mean wind speed $(W s)$ and daily mean wind direction (Wdmean).

Concerning ground-level $\mathrm{O}_{3}$ risk assessment exposure-based standards for vegetation, AOT40 corresponds to the sum of the daylight (8:00-20:00 according to the European Union Directive, 2008/50/EC, and daytime hours with $>50 \mathrm{Wm}^{-2}$ according to the Convention on Long-range Transboundary Air Pollution, CLRTAP) hourly $\mathrm{O}_{3}$ concentrations greater than $40 \mathrm{ppb}$ accumulated at the top of the canopy during the growing season and is calculated by equation (1):

$A O T 40=\sum_{\text {accumulation period }}\left(0 ; C_{c}-40\right) \Delta t$

where $\mathrm{C}_{c}$ represents the $\mathrm{O}_{3}$ concentration value.

According to the European Union (EU) legislation (Directive, 2008/ $50 / \mathrm{EC}$ ), the May to July time window can be used to evaluate the negative effects of ozone (e.g. yield reduction, growth reduction, visible injury) on any kind of vegetation whereas, according to CLRTAP (CLRTAP, 2017b), the AOT40 index can also be used with longer time-windows, such as 6 months (e.g. April to September) corresponding to the growing season of perennial-dominated (semi-)natural vegetation or forest deciduous trees, so that it can be related with growth reduction effects for those vegetation types. The AOT40 indices are commonly associated with exposure-based critical levels $\left(\mathrm{CLe}_{\mathrm{c}}\right.$ ) above which adverse effects on sensitive vegetation may occur according to present knowledge (CLRTAP, 2017b). The EU May-July AOT40 has a $\mathrm{CLe}_{\mathrm{c}}$ value of $9 \mathrm{ppm}-\mathrm{h}$ as 5 -year (or 3-yr) average and $3 \mathrm{ppm}-\mathrm{h}$ as long-target value, which also coincides with the CLRTAP Cle $\mathrm{c}$ value for agricultural crops when applied during a 3-month growing season in a year. However, the CLRTAP $\mathrm{Cle}_{\mathrm{c}}$ value associated to a 6 month time window and growth reduction effects for perennial-dominated (semi) natural vegetation and trees is $5 \mathrm{ppm}-\mathrm{h}$ in a year (Paoletti and Manning, 2007). For grapevine, the only AOT40 $\mathrm{Cle}_{\mathrm{c}}$ published values so far are those related with the experimental work of Soja et al. (1997) which are based on a Welschriesling cultivar exposed to different levels of $\mathrm{O}_{3}$ in open-top-chambers under a continental climate in eastern Austria. This experimental work acknowledged the relevance of a memory effect for a perennial crop such as grapevine, and a $\mathrm{Cle}_{\mathrm{c}}$ of $27 \mathrm{ppm}-\mathrm{h}$ for a $10 \%$ reduction of grape yield was established, without no variation in a second exposure year, whereas the values associated with a $10 \%$ reduction in grape monosaccharide yield were $21 \mathrm{ppm}-\mathrm{h}$ in the first exposure year and $11.5 \mathrm{ppm}-\mathrm{h}$ in the second experimental year.

The cumulative exposure (level-I) approach has been extensively criticized, because it does not reflect the actual dose or flux of $\mathrm{O}_{3}$ entering the plant (Emberson et al., 2000a; Massman, 2004; Mauzerall and Wang, 2001; Musselman et al., 2006; Paoletti and Manning, 2007). To overcome these limitations, a flux-based or level-II approach was developed under the CLRTAP convention (Mills et al., 2011). This approach has a stronger biological basis since it considers a Phytotoxic Ozone Dose (PODY) by considering the $\mathrm{O}_{3}$ stomatal uptake, which can be understood as the amount of $\mathrm{O}_{3}$ molecules that penetrate the leaf tissue through the stomata as a function of ambient $\mathrm{O}_{3}$ concentration and several other critical environmental parameters such as temperature, water vapour pressure, light, soil water potential and plant growth (phenological) stage (Emberson et al., 2000a). PODY is defined as (CLRTAP, 2017b):

$P O D Y=\sum_{\text {accumulation period }}(0 ; \mathrm{Fst}-Y) \Delta t$

where Fst is the instantaneous flux of $\mathrm{O}_{3}$ through the stomatal openings per unit projected leaf area (PLA). It refers specifically to the sunlit leaves at the top of the canopy. It is regarded here as the hourly mean flux of $\mathrm{O}_{3}$ into the stomata. $\mathrm{Y}$ is the threshold stomatal flux per PLA. Both 
parameters have units of $\mathrm{nmol} \mathrm{O}_{3} \mathrm{~m}^{-2} \mathrm{~s}^{-1}$. Critical levels based on stomatal flux $\left(\mathrm{Cle}_{\mathrm{f}}\right)$ are then cumulative stomatal fluxes above which adverse effects may occur according to present knowledge (CLRTAP, 2017b). In a later work, Soja et al. (2004) also published $\mathrm{Cle}_{\mathrm{f}}$ values for grapevine associated with a POD6 index (stomatal $\mathrm{O}_{3}$ flux above $6 \mathrm{nmol}$ $\mathrm{O}_{3} \mathrm{~m}^{-2} \mathrm{~s}^{-1}$ ). A Cle $\mathrm{f}_{\mathrm{f}}$ of $3.5 \mathrm{mmol} \mathrm{m}^{-2}$ for a $10 \%$ reduction of grape yield was established for the first experimental year and $2.2 \mathrm{mmol} \mathrm{m}^{-2}$ for the second year whereas the values associated with a $10 \%$ reduction in grape monosaccharide yield were $2.3 \mathrm{mmol} \mathrm{m}^{-2}$ in the first year of the experiment and $1.1 \mathrm{mmol} \mathrm{m}^{-2}$ in the second year.

Both AOT40 and POD based approaches were used to assess our model results and measurements. The ground-level $\mathrm{O}_{3}$ variables and vegetation risk assessment standards selected for evaluation of the simulations were the following: daily $\mathrm{O}_{3} \max \left(\mathrm{O}_{3} \max \right)$, hourly $\mathrm{O}_{3}$ mean $\left(\mathrm{O}_{3}\right.$ mean), EU legislation-based May to July AOT40 (May-Jul AOT40), CLRTAP-based April to September AOT40 (Apr-Sep AOT40), June to September AOT40 as proposed by Soja et al. $(1997,2004)$ for the grapevine (Jun-Sep AOT40), CLRTAP-based April to September POD (Apr-Sep POD), June to September POD as proposed by Soja et al. (1997, 2004) for the grapevine (Jun-Sep POD), CLRTAP-based April to September POD6 (Apr-Sep POD6), and June to September POD6 as proposed by Soja et al. $(1997,2004)$ for the grapevine (June-Sep POD6).

\subsection{Assessment of modelling performance}

Considering several studies (Borrego et al., 2008; Emery et al., 2017; Marta-Almeida et al., 2016; Politi et al., 2017; Soares et al., 2012; Willmott et al., 2012; Zittis et al., 2014) related to assess photochemical and meteorological model performance, the following methods and statistics were selected:

\subsubsection{Daily scale}

1. Time series plots of field data versus $1 \mathrm{~km}$ WRF-CHIMERE results.

2. Comparison of the probability distributions of the observed and modelled variables including a statistical test, the KolmogorovSmirnov (KS) test.

3. Evaluation metrics, such as the bias (BIAS), the ratio of the standard deviation between modelled and observed variables (SD Ratio), the mean absolute error (MAE), the mean absolute percent error (MAPE), the root mean square error (RMSE), the Pearson's correlation coefficient (CORR), and the modified index of agreement (MIA). For wind direction, MIA was replaced by the standard deviation of the errors (STDE), as it can be taken as an indicator of correct simulations physics if it is low, even when there is high BIAS or RMSE (Carvalho et al., 2012).

\subsubsection{Hourly scale}

1. Taylor diagrams, which also include correlations between observed and modelled variables, similarity in variable distributions (standard deviation comparisons) and root mean square error (RMSE).

Regional weather and chemical transport models can exhibit systematic simulation biases. When that is the case, the simulations could be post-processed in order to obtain more reliable estimates of the local weather or ambient air pollutants. Among the diversity of methods available, a non-parametric quantile-quantile (QQ) transformation was selected due to its relative simplicity and good skill to reduce bias in modelled fields, such as precipitation, as suggested by Gudmundsson et al. (2012). The QQ transformation was only applied to the WRF-CHIMERE final results related to $\mathrm{O}_{3}$ phytotoxic risk assessment, ambient $\mathrm{O}_{3}$ and $\mathrm{O}_{3}$ stomatal flux.

For the comparison between modelled and measured values, a cell bilinear interpolation filter was applied to the WRF-CHIMERE neighbouring cells to the location of the field observational stations. Next, the results of comparing the meteorological and air quality simulated and measured values are presented.

\section{Results and discussion}

This section focuses first on results related with temperature, global solar radiation, relative humidity, and wind as principal meteorological drivers related to plant $\mathrm{O}_{3}$ exposure and phytotoxic $\mathrm{O}_{3}$ dose. Results related with daily $\mathrm{O}_{3} \max$, hourly $\mathrm{O}_{3}$ mean profiles, and seasonal standards for vegetation protection are described afterwards. The relevance of simulation bias, field campaign data for model parametrization and validation, and variability and significance of results also in relation to climate extremes is discussed.

\subsection{Meteorological variables}

Tables $2-5$ present the obtained validation statistics for temperature, global solar radiation, relative humidity and wind speed and direction, respectively. These statistics are based on modelled WRF results versus observed values at Vila Real (R1), Pinhão (R2) and Quinta da Leda (R3), during the 2017 Apr-Sep grapevine growing season. Further information, namely maps, time series, density plots and Taylor diagrams can be assessed in the Supplementary Material.

The measured daily Tmax mean and standard deviation increased from the most northwestern location (Vila Real) to the most southeastern one (Quinta da Leda). The average bias of the WRF simulations increased from the northwest to the southeast too. The linear correlation was very strong $(C O R R>0.90)$ in all cases. The SD ratios also indicated a similar spread of the observed and modelled data.

Table 2

Validation statistics for daily Tmax and hourly Tmean (April-September 2017 period).

\begin{tabular}{|c|c|c|c|c|c|c|c|c|}
\hline Daily $\operatorname{Tmax}\left({ }^{\circ} \mathrm{C}\right)$ & Field value & BIAS & SD Ratio & MAE & MAPE (\%) & RMSE & CORR & MIA \\
\hline Vila Real & $\begin{array}{l}26.0(\mu) \\
5.4(\sigma)\end{array}$ & -1.5 & 0.98 & 2.0 & 8.0 & 2.5 & 0.93 & 0.78 \\
\hline Pinhão & $\begin{array}{l}30.7(\mu) \\
5.4(\sigma)\end{array}$ & -2.7 & 0.99 & 2.9 & 9.7 & 3.4 & 0.92 & 0.68 \\
\hline Quinta da Leda & $\begin{array}{l}31.5(\mu) \\
5.7(\sigma)\end{array}$ & -3.1 & 0.97 & 3.3 & 10.5 & 3.7 & 0.93 & 0.66 \\
\hline Hourly Tmean $\left({ }^{\circ} \mathrm{C}\right)$ & Field value & BIAS & SD Ratio & MAE & MAPE (\%) & RMSE & CORR & MIA \\
\hline Vila Real & $\begin{array}{l}19.1(\mu) \\
6.3(\sigma)\end{array}$ & -0.7 & 0.97 & 2.1 & 11.6 & 2.5 & 0.92 & 0.80 \\
\hline Pinhão & $\begin{array}{l}22.4(\mu) \\
7.0(\sigma)\end{array}$ & -1.6 & 0.95 & 3.0 & 14.3 & 3.2 & 0.89 & 0.73 \\
\hline Quinta da Leda & $\begin{array}{l}23.1(\mu) \\
7.4(\sigma)\end{array}$ & -1.8 & 0.93 & 2.2 & 10.1 & 2.0 & 0.96 & 0.81 \\
\hline
\end{tabular}


Table 3

Validation statistics for daily Radmax and hourly Rad (April-September 2017 period).

\begin{tabular}{|c|c|c|c|c|c|c|c|c|}
\hline Daily Radmax $\left(\mathrm{kJ} \mathrm{m}^{-2}\right)$ & Field value & BIAS & SD Ratio & MAE & MAPE (\%) & RMSE & CORR & MIA \\
\hline Vila Real & $3159(\mu) 478(\sigma)$ & 110 & 0.66 & 227 & 9.3 & 409 & 0.57 & 0.65 \\
\hline Pinhão & $3227(\mu) 440(\sigma)$ & 29 & 0.71 & 217 & 8.2 & 365 & 0.57 & 0.63 \\
\hline Quinta da Leda & $3410(\mu) 452(\sigma)$ & -132 & 0.68 & 332 & 10.5 & 402 & 0.55 & 0.44 \\
\hline Hourly Rad (kJ m $\left.{ }^{-2}\right)$ & Field value & BIAS & SD Ratio & MAE & MAPE (\%) & RMSE & CORR & MIA \\
\hline Vila Real & $993(\mu) 1210(\sigma)$ & 44 & 1.03 & 159 & - & 368 & 0.96 & 0.93 \\
\hline Pinhão & $981(\mu) 1225(\sigma)$ & 59 & 1.02 & 277 & - & 470 & 0.93 & 0.87 \\
\hline Quinta da Leda & $1081(\mu) 1301(\sigma)$ & -39 & 0.96 & 272 & - & 456 & 0.94 & 0.88 \\
\hline
\end{tabular}

Table 4

Validation statistics for daily RHmin and hourly RHmean (April-September 2017 period).

\begin{tabular}{|c|c|c|c|c|c|c|c|c|}
\hline Daily RHmin (\%) & Field value & BIAS & SD Ratio & MAE & MAPE (\%) & RMSE & CORR & MIA \\
\hline Vila Real & $37.3(\mu) 12.6(\sigma)$ & -2.5 & 1.01 & 6.7 & 18.4 & 8.8 & 0.78 & 0.69 \\
\hline Pinhão & $22.3(\mu) 9.5(\sigma)$ & 6.9 & 1.10 & 8.1 & 44.6 & 9.8 & 0.76 & 0.53 \\
\hline Quinta da Leda & $22.7(\mu) 8.9(\sigma)$ & 3.2 & 1.01 & 5.6 & 28.7 & 7.1 & 0.75 & 0.61 \\
\hline Hourly RHmean (\%) & Field value & BIAS & SD Ratio & MAE & MAPE (\%) & RMSE & CORR & MIA \\
\hline Vila Real & $59.9(\mu) 20.3(\sigma)$ & -3.3 & 0.95 & 9.5 & 16.5 & 12.4 & 0.82 & 0.72 \\
\hline Pinhão & $46.3(\mu) 19.7(\sigma)$ & 6.0 & 0.97 & 10.2 & 28.1 & 12.4 & 0.84 & 0.70 \\
\hline Quinta da Leda & $45.7(\mu) 19.3(\sigma)$ & 3.1 & 0.99 & 7.8 & 19.8 & 9.9 & 0.88 & 0.76 \\
\hline
\end{tabular}

The hourly Tmean evaluation metrics were similar to those of the daily Tmax data, although there was a lower bias and a better model agreement reflected by higher MIA in all cases and the worst WRF performance was at the Pinhão location as revealed by its higher MAE and RMSE error (Table 2).

The higher Tmean error statistics estimated for the Pinhão were most likely associated with the greater difficulty to model the Mediterranean conditions present at the lower altitudes and deep and narrow valley locations (Fig. 1d), in contrast with those present in the sub-plateau Vila Real location (Fig. 1c) or more open Mediterranean locations towards the east such as Quinta da Leda (Fig. 1e). Those conditions were more pronounced for daily Tmax with the model indicating worse accuracy and precision for both Pinhão and Quinta da Leda than for the subplateau Vila Real location under a more sub-Atlantic climate influence. This was also in connection with the greater difference between the station elevation and the value used by the model as derived from the digital elevation model (DEM), respectively 130 and $225 \mathrm{~m}$ for Pinhão, 228 and $278 \mathrm{~m}$ for Quinta da Leda, and 561 and $568 \mathrm{~m}$ for Vila Real.

Overall, the results indicate a good agreement concerning patterns at the seasonal, daily and hourly scale for temperature, with probability distributions and error statistics within the range of those reported by other studies about the validation of WRF simulations in the Iberian Peninsula (Marta-Almeida et al., 2016; Soares et al., 2012) and other Mediterranean areas such as Greece (Politi et al., 2017). For instance, according to Soares et al. (2012) the validation statistics for a $5 \mathrm{~km}$ horizontal resolution WRF simulation for northeastern Portugal presented the following range for daily Tmax: CORR $\geq 0.90$, BIAS $-3.3-$ $0.5^{\circ} \mathrm{C}$, RMSE $2.5-4.6^{\circ} \mathrm{C}$. This range of values is very similar to those found in Table 2 for daily Tmax.

The final text should be as follows here:

Table 3, with validation statistics for solar radiation, shows that there was a better match between measured and modelled daily Radmax for Vila Real and Pinhão than for Quinta de Leda where the WRF simulations had greater MAE and RMSE and lower MIA. Quinta da Leda was also distinctive for displaying a clear negative bias. The simulations did not capture well some minima values resulting in moderate correlations and fairly low MIA values, specifically for the most southeastern location, Quinta da Leda. For all cases, the spread of the Radmax modelled data was lower than that of the observations resulting in low SD ratios.

In Table 3 it can also be observed that the performance of the WRF model improved in relation with hourly mean Rad with much greater MIA and CORR values in comparison with the daily Radmax case. Quinta da Leda showed again the higher hourly mean value but the differences among stations concerning average Rad values were smaller than for Radmax. All in all, the model performed slightly better for the higher sub-plateau location, with correlation and precision improving considerably at the hourly scale at all locations. The magnitude of the errors and correlation statistics shown for hourly Rad in Table 3 were very close or within the range of other validation studies performed with WRF solar radiation simulations in the Iberian peninsula (López et al., 2020; Perdigão et al., 2017) and France (Boulard et al., 2016). For instance, according to López et al. (2020), the validation statistics for a $1 \mathrm{~km}$ horizontal resolution WRF simulation for central continental

Table 5

Validation statistics for hourly Ws and daily Wdmean (April-September 2017 period).

\begin{tabular}{|c|c|c|c|c|c|c|c|c|}
\hline Hourly Ws (m/s) & Field value & BIAS & SD Ratio & MAE & MAPE (\%) & RMSE & CORR & MIA \\
\hline Vila Real & $\begin{array}{l}1.8(\mu) \\
1.3(\sigma)\end{array}$ & 1.1 & 1.36 & 1.3 & - & 1.7 & 0.65 & 0.50 \\
\hline Pinhão & $\begin{array}{l}1.9(\mu) \\
1.1(\sigma)\end{array}$ & 0.8 & 1.78 & 1.3 & - & 1.8 & 0.63 & 0.48 \\
\hline Quinta da Leda & $\begin{array}{l}1.4(\mu) \\
1.3(\sigma)\end{array}$ & 1.4 & 1.50 & 1.6 & - & 2.1 & 0.59 & 0.41 \\
\hline Daily Wdmean $\left(^{\circ}\right)$ & Field value & BIAS & SD Ratio & MAE & MAPE (\%) & RMSE & CORR & STDE \\
\hline Vila Real & $\begin{array}{l}284(\mu) \\
46(\sigma)\end{array}$ & 24.7 & 1.17 & 34.9 & 12.3 & 50.9 & 0.72 & 44.5 \\
\hline Pinhão & $\begin{array}{l}336(\mu) \\
37(\sigma)\end{array}$ & -9.6 & 1.73 & 94.4 & 28.1 & 103.4 & -0.39 & 102.9 \\
\hline Quinta da Leda & $\begin{array}{l}279(\mu) \\
58(\sigma)\end{array}$ & 10.2 & 0.88 & 38.9 & 13.9 & 54.0 & 0.24 & 53.1 \\
\hline
\end{tabular}


Portugal presented the following ranges for daily Radmax radiation and hourly Rad: BIAS -72 - $324 \mathrm{~kJ} \mathrm{~m}^{-2}$, MAE 108-378 kJ m${ }^{-2}$, RMSE $180-558 \mathrm{~kJ} \mathrm{~m}^{-2}$ (Radmax) and BIAS 3.6-144 kJ m-2, MAE 144-216 kJ $\mathrm{m}^{-2}$, RMSE 216-396 kJ m ${ }^{-2}$ (Rad).

The relative humidity validation statistics included in Table 4 show that linear correlation was strong for daily RHmin in all three locations, but BIAS, MAPE, RMSE and MIA indicated a better performance of the simulations for the Vila Real location. The hourly mean $R H$ values also followed and inverse relationship with hourly Tmean with decreasing values from the NW to the SE (Table 4). There was also better performance of the WRF model in all cases if compared with daily RHmin with slightly higher correlation and MIA statistics. However, the WRF model performance was now better at Quinta da Leda as observed by its higher MIA and lower MAE and RMSE errors. The validation statistics were within or close to the range of other WRF mesoescale simulation studies (Boulard et al., 2016; Kryza et al., 2017; López et al., 2020; Pan and Li, 2011). For instance, the error range for a one year $5 \mathrm{~km}$ horizontal resolution WRF simulation after comparison with data from 7 meteorological stations in the Heihe river basin (continental China) reported by Pan and Li (2011) for hourly $R H$ was the following: CORR 0.55-0.75, BIAS -7.3-13.3\%, RMSE 16.5-23.6\%).

The validation statistics for wind speed and wind direction can be found in Table 5. Hourly Ws correlation values varied from 0.59 (Quinta da Leda) to 0.65 (Vila Real), and the accuracy values provided by MIA were low. The daily Wdmean clockwise bias for Vila Real was $24.7^{\circ}$ and $10.2^{\circ}$ for Quinta da Leda with respective STDE 44.5 and 53.1 (Table 5). The greatest divergence was found for the Pinhão location where the simulated wind direction was $269^{\circ}$ compared to the $336^{\circ}$ observed one. The results for the Pinhão location probably were related to the more sheltered location of the monitoring station along the Douro's river canyon which is not fully captured by the WRF model. In fact, we have already pointed out that the Pinhão station had the greatest difference between measured ground altitude and the altitude used by the WRFCHIMERE modeling system (130 m and $225 \mathrm{~m}$, respectively). The worse model performances concerning precision and accuracy were also found for the Pinhão location for hourly Tmean, hourly Rad, daily RHmin and hourly $R H$, although the differences in these cases were rather slight when compared with the other locations.

Overall, the WRF wind simulation for the 2017 Apr-Sep grapevine growing season in the DDR can be associated to the predominance of westerly-north-westerly flows, which result from the deflection of the northerly winds of the Atlantic coast, by the orientation of the valley and by the Iberian thermal low favoured by most of the synoptic weather situations in areas such as the Douro river basin (Lorente-Plazas et al., 2015). Except for daily Wdmean at the Pinhão location, the error statistics estimated for wind velocity and wind direction at the daily and hourly scale were very close or within the range found by other WRF mesoscale validation studies where the greater inaccuracies were also associated with mismatches between the model and the actual terrain elevation and the inability to reproduce the lower atmosphere conditions of complex terrains (Jiménez et al., 2013; Pan et al., 2018; Pan and Li, 2011; Zhang et al., 2013). For instance, the work by Pan and Li (2011) concerning one year $5 \mathrm{~km}$ horizontal resolution WRF simulation in the Heihe river basin (continental China) presented the following error statistics for hourly $W s$ : BIAS from -0.6 to $1.8 \mathrm{~m} / \mathrm{s}$, RMSE from 1.3 to $3.6 \mathrm{~m} / \mathrm{s}$. As for daily Wdmean, Carvalho et al. (2012) reported the following statistics at hourly level from a $3.6 \mathrm{~km}$ horizontal resolution WRF simulation performed during January in a mountainous area of central Portugal: BIAS from $-3.8^{\circ}$ to $-9.7^{\circ}$, RMSE $37.3^{\circ}$ to $52.0^{\circ}$, and STDE from $37.2^{\circ}$ to $51.1^{\circ}$.

In summary, excepting for the meteorological variables associated to wind, it has been observed that model performance tended to be more precise and accurate when hourly values are analyzed than when considering daily maxima data. Differences among locations were slight, apart from Radmax and RHmin where there was a drop in model performance (MIA < 0.6) for one of the sites (Quinta da Leda for Radmax and Pinhão for RHmin). Validation statistics were acceptable and within the range of what has been found in other RCM simulations with the lower values associated to the moderate correlations estimated for Radmax (between 0.55 and 0.57). Model accuracy performance was lower (MIA < 0.6) for all observational sites for wind speed and there was only a strong correlation value for wind direction in one of the locations (Vila Real).

\subsection{Ground-level $\mathrm{O}_{3}$}

Table 6 and Fig. 2 show the validation statistics and graphs, respectively, associated with ground-level $\mathrm{O}_{3}$ values at Douro Norte and Quinta da Leda air quality stations. The measured values for daily $\mathrm{O}_{3}$ maxima and hourly $\mathrm{O}_{3}$ means were similar in the two sites. The correlation values were moderate for daily $\mathrm{O}_{3}$ maxima and strong for hourly $\mathrm{O}_{3}$ at Quinta da Leda, whereas they were strong for daily $\mathrm{O}_{3}$ maxima and hourly values at Douro Norte. The BIAS, RMSE, MAE and MAPE errors were lower for the Quinta da Leda site and the SD ratios indicated a lower spread of the simulated values for both locations. The lower spread of the simulated values was also observable in the time series plots (Fig. 2a), where the simulated values failed to capture the maxima and minima values, and in the density plots (Fig. 2b), where the KS test indicated significant differences between the distribution of observed and simulated data ( $\mathrm{p}<0.01$ ). The Taylor diagrams (Fig. 2c) for the hourly $\mathrm{O}_{3}$ mean values indicated a similar WRF-CHIMERE model performance for the two sites at the hourly scale. Monteiro et al. (2012) in a previous simulation of a high $\mathrm{O}_{3}$ episode in the Douro Norte site presented higher error statistics and similar correlation values. However, as the MIA values were low for all cases, a QQ statistical transformation of the WRF-CHIMERE $\mathrm{O}_{3}$ simulated values was applied in order to be able to use them for vegetation risk assessment.

Table 7 presents the validation statistics after the QQ transformation and Fig. 3 illustrates the results of the QQ transformation, in terms of monthly and hourly boxplots, where the spread of the simulated values is closer to that of the observed ones.

The QQ transformation corrected the BIAS and lowered the spread of the hourly $\mathrm{O}_{3}$ mean simulated data yielding a better model performance as also observed in the lower error MAE and RMSE statistics and higher MIA. Daily $\mathrm{O}_{3}$ max simulated values also approximated better the range of the observed values with a higher MIA although the effects on error statistics such as BIAS, MAE and RMSE were negligible. CORR was not affected by the QQ transformation.

Previous studies for an elevated site such as the Douro Norte (Carvalho et al., 2010; Sousa et al., 2011) also highlighted a drop in values from July to September, which was captured by the simulations (before and after the QQ transformation). As it happened with the Douro Norte site, the seasonal and hourly time patterns were also well captured by the simulations for Quinta da Leda. Although there were no previous measurements for the Quinta da Leda site, which displayed a more marked hourly variation, Pires et al. (2012) mentioned this type of hourly behavior as typical of lower elevation rural stations in northern Portugal.

Concerning AOT40 indices estimated at Quinta da Leda (Table 8), the measured EU May-Jul AOT40 value ( $8 \mathrm{ppm} \mathrm{h}$ ) exceeded the longtarget value of $3 \mathrm{ppm} \mathrm{h}$ and was close to what has been set as the general standard to protect vegetation ( 9 ppm h) by Directives (2002)/03/ EC and 2008/50/EC. Higher mean values (11 ppm h) were frequently observed at the Douro Norte monitoring station in the past (Agência Portuguesa do Ambiente, 2009, 2011) between 2005 and 2010. Thus, probably the standard set to protect vegetation would also be exceeded at Quinta da Leda for longer exposure years. The measured day light-based Apr-Sep AOT4O (13.8 ppm h) exceeded the Cle $\mathrm{c}_{\mathrm{c}}(5 \mathrm{ppm} \mathrm{h})$ for a $5 \%$ biomass reduction in perennial-dominated (semi)natural vegetation and trees. The field Jun-Sep AOT40 reached $9.5 \mathrm{ppm}$ h but is below the specific yearly $\mathrm{Cle}_{\mathrm{c}}$ values for a $10 \%$ reduction in yield and quality (27 ppm h and $21 \mathrm{ppm} \mathrm{h}$, respectively) as set by Soja et al. (1997) for the 
Table 6

Validation statistics for daily $\mathrm{O}_{3}$ max and hourly $\mathrm{O}_{3}$ mean (April-September 2017 period).

\begin{tabular}{|c|c|c|c|c|c|c|c|c|}
\hline Daily $\mathrm{O}_{3} \max (\mathrm{ppb})$ & Field value & BIAS & SD Ratio & MAE & MAPE (\%) & RMSE & CORR & MIA \\
\hline Douro Norte & $50(\mu) 15(\sigma)$ & 5 & 0.57 & 10 & 21.3 & 12 & 0.68 & 0.46 \\
\hline Quinta da Leda & $55(\mu) 11(\sigma)$ & 1 & 0.55 & 7 & 12.7 & 9 & 0.55 & 0.46 \\
\hline Hourly $\mathrm{O}_{3}$ mean (ppb) & Field value & BIAS & SD Ratio & MAE & MAPE (\%) & RMSE & CORR & MIA \\
\hline Douro Norte & $38(\mu) 12(\sigma)$ & 12 & 0.59 & 13 & 42.0 & 14 & 0.69 & 0.39 \\
\hline Quinta da Leda & $41(\mu) 12(\sigma)$ & 7 & 0.70 & 9 & 27.3 & 11 & 0.70 & 0.51 \\
\hline
\end{tabular}
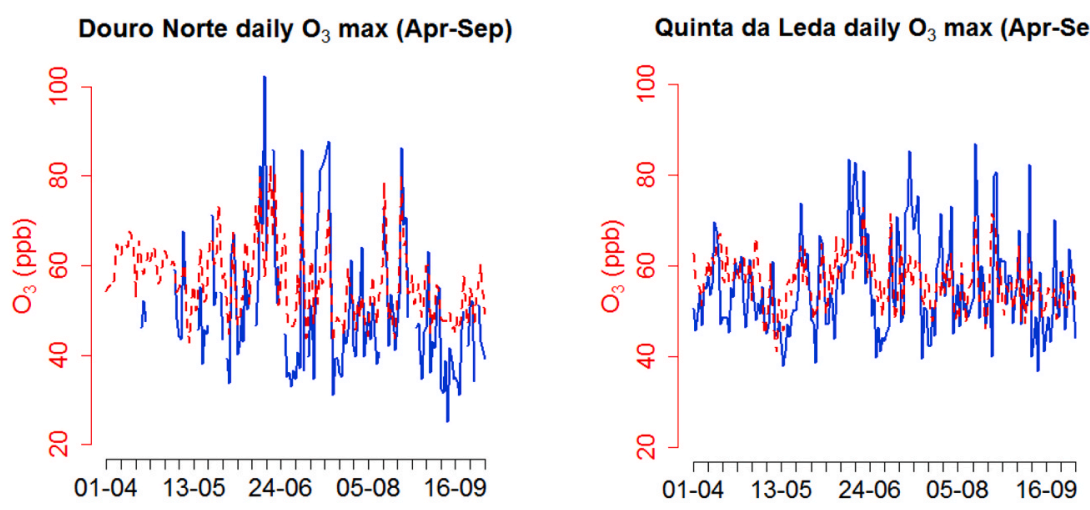

a)
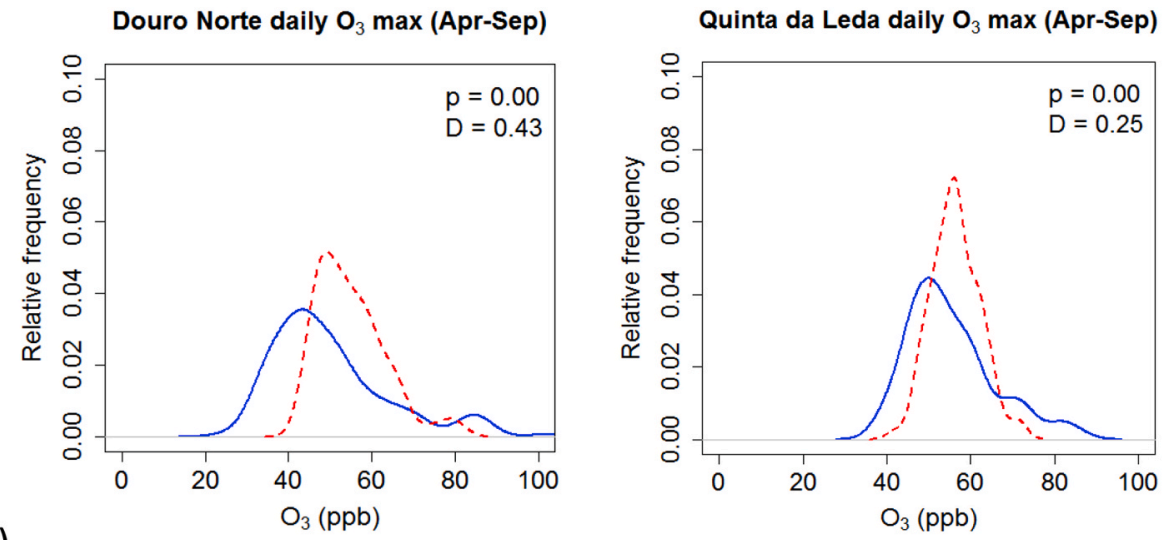

b)
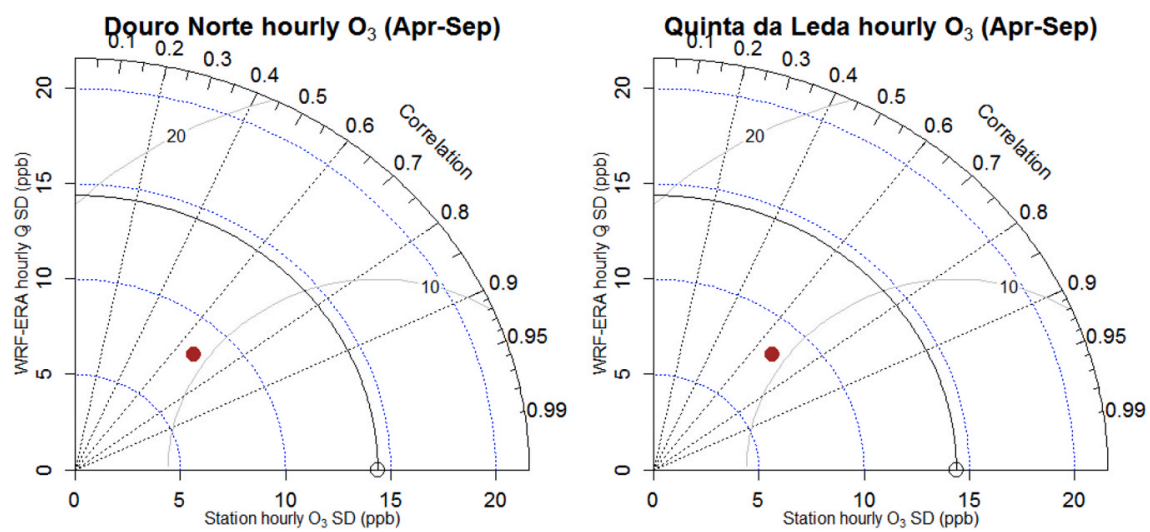

c)

Fig. 2. a) Time series, b) density plots, and c) Taylor diagrams for ground-level $\mathrm{O}_{3}$.

Welschriesling grapevine cultivar. WRF-CHIMERE simulated values were higher (16.2 ppm h) than measurements and they could indicate risk of exceeding the $\mathrm{Cle}_{\mathrm{c}}$ for a $10 \%$ reduction in monosaccharide yield over two consecutive years (11.5 ppm h), if there was not ground control, and no fit to observational data, as the QQ transformation was not be applied. 
Table 7

Validation statistics for QQ transformed daily $\mathrm{O}_{3}$ maxima $\left(\mathrm{O}_{3} \max \right)$ and hourly $\mathrm{O}_{3}$ means $\left(\mathrm{O}_{3}\right.$ mean $)$.

\begin{tabular}{|c|c|c|c|c|c|c|c|c|}
\hline Daily $O_{3} \max (\mathrm{ppb})$ & Field value & BIAS & SD Ratio & MAE & MAPE (\%) & RMSE & CORR & MIA \\
\hline Douro Norte & $\begin{array}{l}50(\mu) \\
15(\sigma)\end{array}$ & -5 & 1.03 & 9 & 17.2 & 13 & 0.66 & 0.61 \\
\hline Quinta da Leda & $\begin{array}{l}55(\mu) \\
11(\sigma)\end{array}$ & -1 & 1.01 & 8 & 14.0 & 10 & 0.54 & 0.54 \\
\hline Hourly $\mathrm{O}_{3}$ mean (ppb) & Field value & BIAS & SD Ratio & MAE & MAPE (\%) & RMSE & CORR & MIA \\
\hline Douro Norte & $\begin{array}{l}38(\mu) \\
12(\sigma)\end{array}$ & 0 & 0.98 & 7 & 20.5 & 9 & 0.68 & 0.61 \\
\hline Quinta da Leda & $\begin{array}{l}41(\mu) \\
12(\sigma)\end{array}$ & 0 & 1.01 & 7 & 18.7 & 9 & 0.70 & 0.63 \\
\hline
\end{tabular}

a)

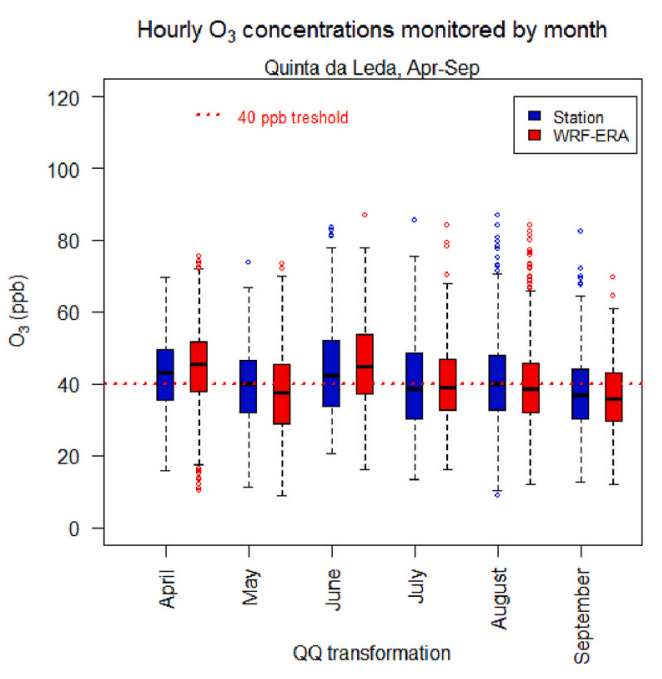

Hourly $\mathrm{O}_{3}$ concentrations monitored by month

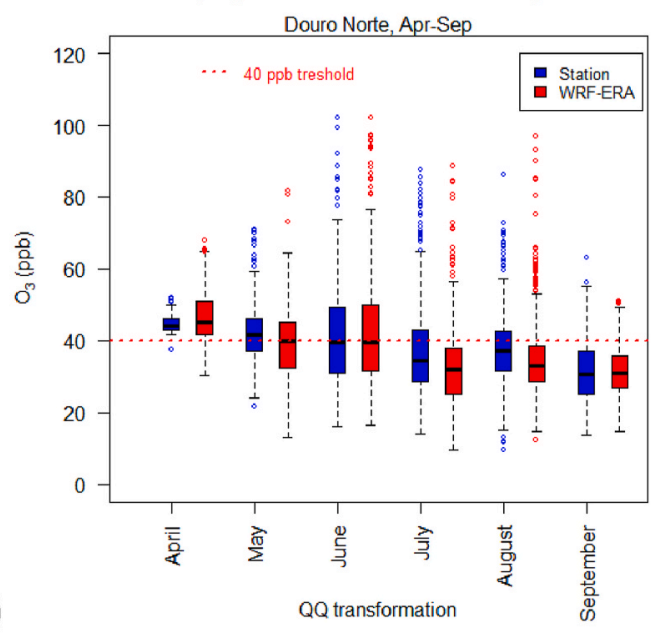

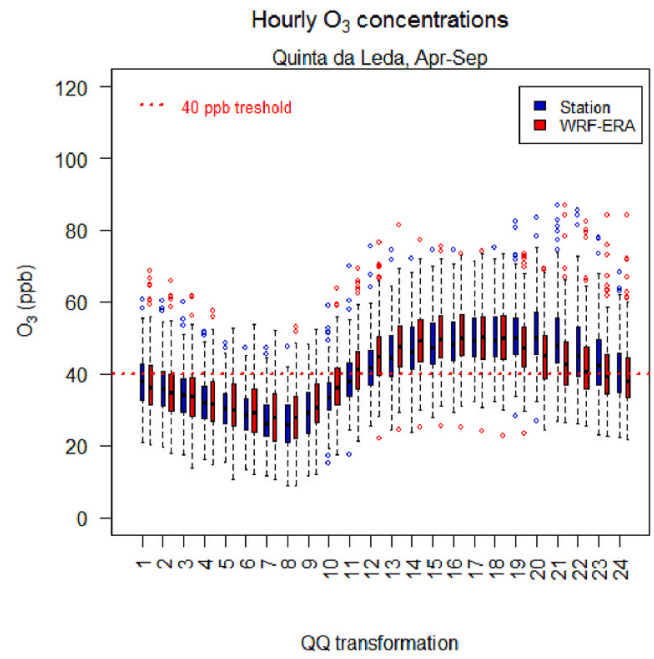

Hourly $\mathrm{O}_{3}$ concentrations monitored by month

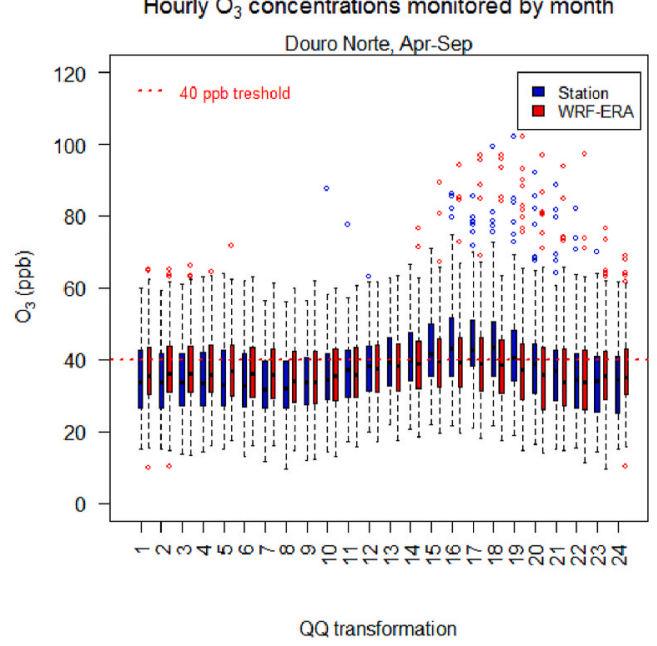

Fig. 3. a) Monthly, and b) hourly boxplot $\mathrm{O}_{3}$ profiles at Quinta da Leda and Douro Norte.

Table 8

$\mathrm{O}_{3}$ exposure indices estimated at Quinta da Leda.

\begin{tabular}{|c|c|c|c|c|c|c|c|c|}
\hline \multicolumn{3}{|c|}{ EU May-Jul AOT4O (ppm.h) } & \multicolumn{3}{|c|}{ Jun-Sep AOT4O (ppm.h) } & \multicolumn{3}{|c|}{ CLRTAP Apr-Sep AOT4O (ppm.h) } \\
\hline Field & WRF-CHIMERE & QQ Trans & Field & WRF-CHIMERE & QQ Trans & Field & WRF-CHIMERE & QQ Trans \\
\hline 8.1 & 12.3 & 8.5 & 9.5 & 16.2 & 10.6 & 13.8 & 24.5 & 16.6 \\
\hline
\end{tabular}

Fig. 4 presents maps of QQ transformed AOT exposure simulated values. The daily mean maxima Apr-Sep $\mathrm{O}_{3}$ values show that larger values were associated to higher elevations in the Marão and Montemuro mountain ranges towards the northwest of the DDR and spread through the Douro valley across the DDR (Fig. 4b). Daily mean Apr-Sep $\mathrm{O}_{3}$, EU's May-Jul AOT40 and CLRTAP Apr-Sep AOT40 (Fig. 4a, c and d) had similar spatial patterns with higher $\mathrm{O}_{3}$ concentrations associated mostly with higher elevations (Fig. 4f) inside and outside the DDR and 


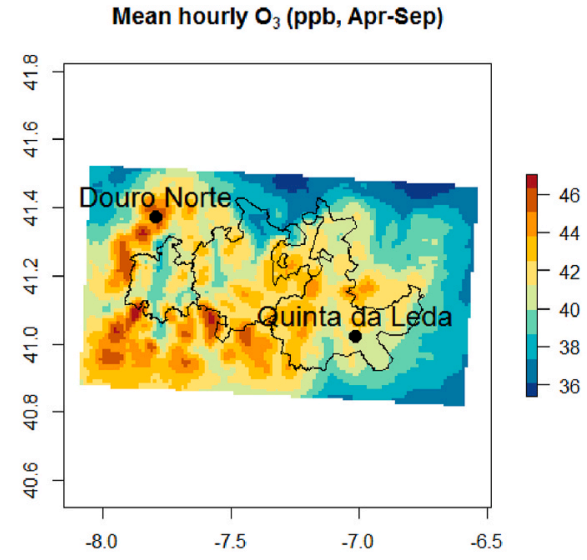

a)

$Q Q$ transformation

EU AOT40 (ppm.h, May-Jul)

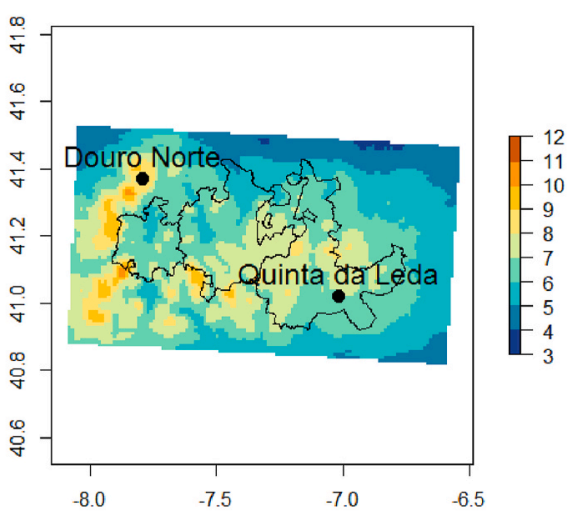

c)

Soja's AOT40 (ppm.h, Jun-Sep)

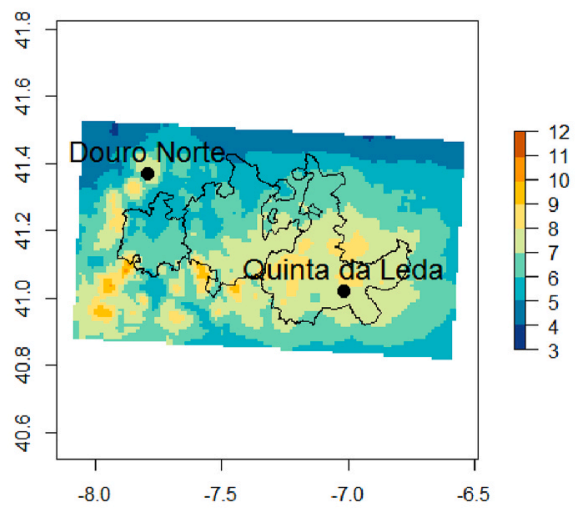

e)

QQ transformation

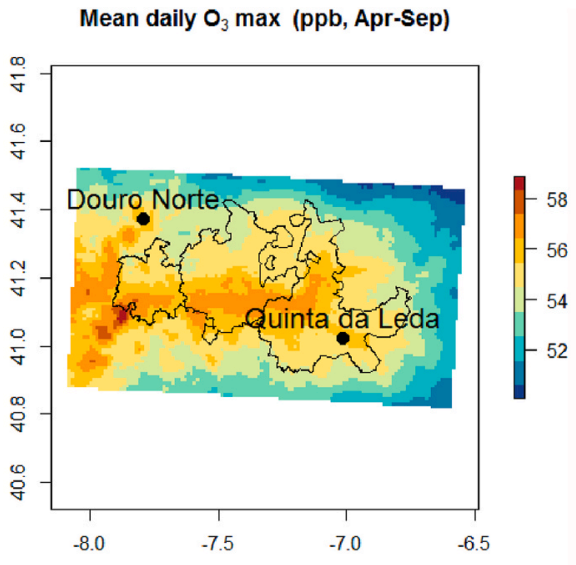

b)

QQ transformation

CLRTAP AOT40 (ppm.h, Apr-Sep)

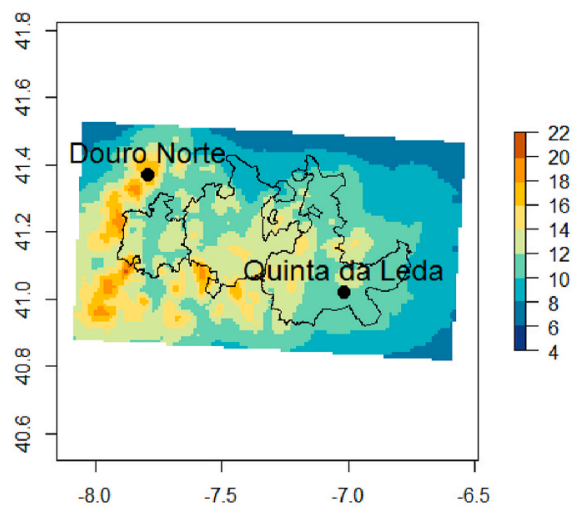

d)

QQ transformation

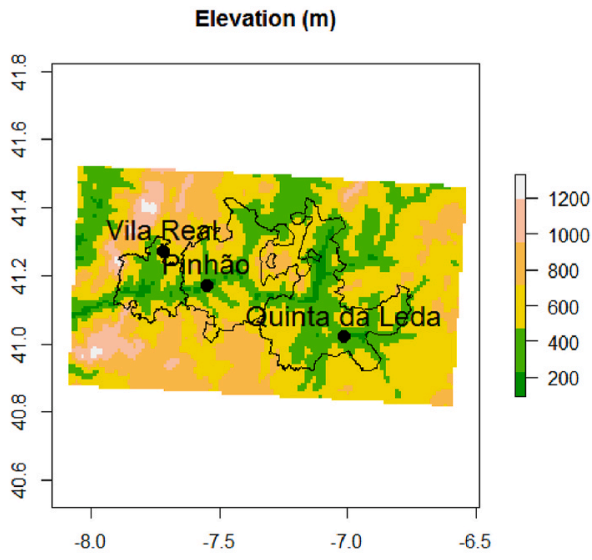

f)

USGS Topography

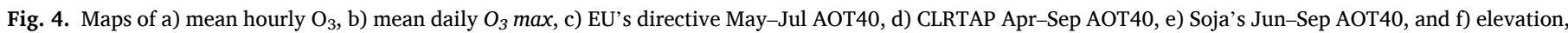
as obtained from the WRF-CHIMERE transformed simulations and associated elevation database.

particularly affecting a transitional area between the Cima Corgo and the Douro Superior subregions within the DDR. The AOT40 estimated according the procedure of Soja's (Fig. 4e) indicates that besides the previously commented areas, most of the Douro Superior subregion, with a warmer and drier climate, can be affected by high $\mathrm{O}_{3}$ levels between June and September (Jun-Sep).

\section{3. $\mathrm{O}_{3}$ uptake by stomata}

Table 9 and Fig. 5 present the $\mathrm{O}_{3}$ dose values expressed as POD and POD6, based on measurements and simulations.

The observational based stomatal flux and the WRF-CHIMERE based stomatal flux presented a similar temporal pattern at Quinta da Leda 
$\mathrm{POD}$ (Stomatal $\mathrm{O}_{3}$ flux $\mathrm{mmol} \mathrm{m}^{-2}$, Apr-Sep)

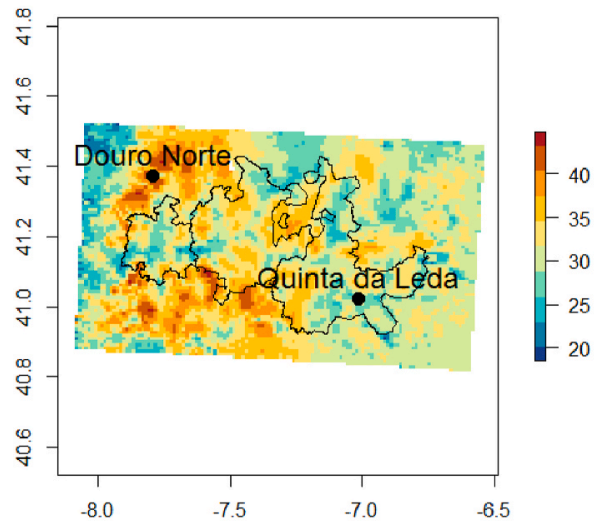

a)

c)

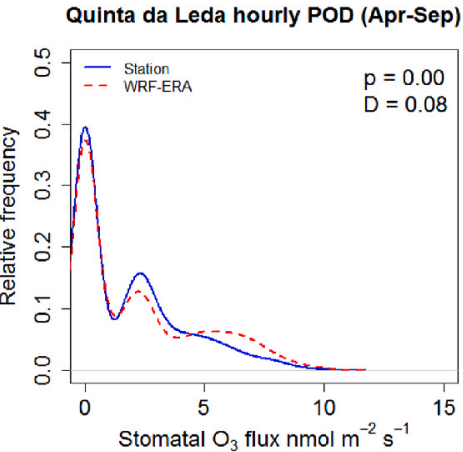

Quinta da Leda hourly POD (Apr-Sep)

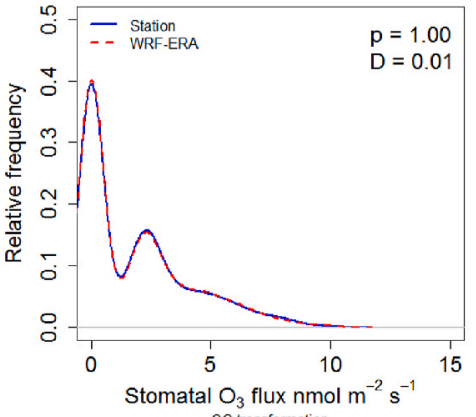

e)

QQ transformation

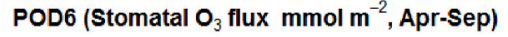

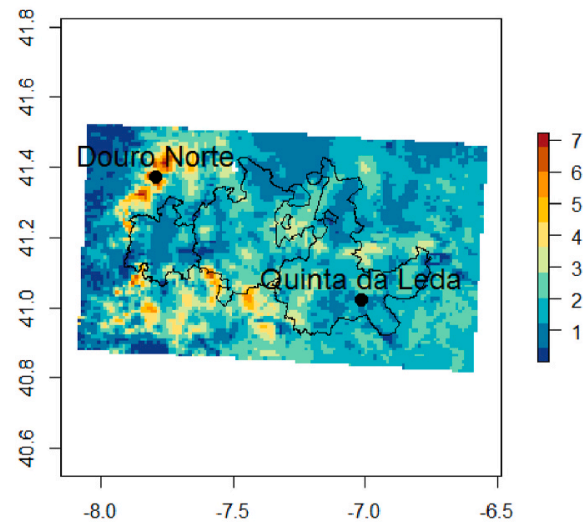

b)

QQ transformation

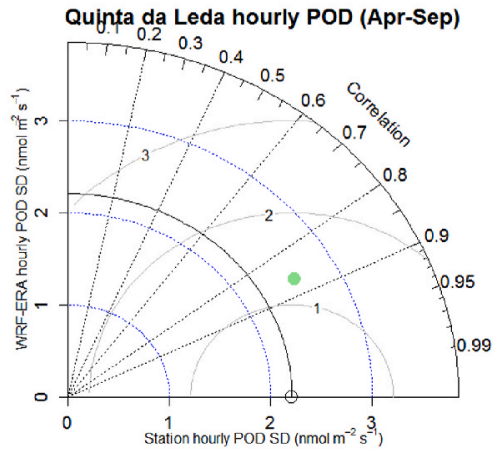

d)

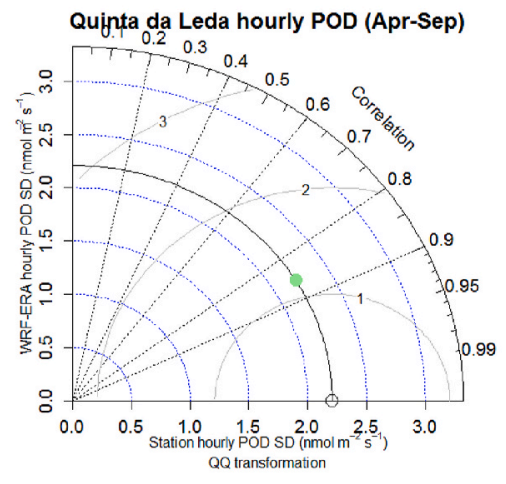

f)

Fig. 5. a,b) QQ transformed Apr-Sep (AS) POD and POD6 maps for the DDR, c,d) Density and Taylor plots for Apr-Sep first POD estimates and for e,f) QQ transformed POD at Quinta de Leda.

with a $17 \%$ and $50 \%$ positive difference for Apr-Sep POD and Apr-Sep POD6, respectively, when these are estimated from WRF-CHIMERE without any statistical transformation (Table 9). A field-observational exceedance of the grapevine $\mathrm{Cl}_{\mathrm{ef}}$ for $10 \%$ reduction in monosaccharide concentrations over consecutive years $\left(1.1 \mathrm{mmol} \mathrm{m}^{-2}\right)$, as derived from Soja et al. (2004), was observed at Quinta da Leda with a POD6 of 1.2

Table 9

Observational and WRF-CHIMERE-based POD and POD6.

\begin{tabular}{llllll}
\hline \multicolumn{2}{l}{ April to September POD $\left(\mathrm{mmol} \mathrm{m}^{-2}\right)$} & \multicolumn{4}{l}{ April to September POD6 $\left(\mathrm{mmol} \mathrm{m}^{-2}\right)$} \\
\hline Field & WRF-CHIMERE & QQ Trans & Field & WFR-CHIMERE & QQ Trans \\
28.3 & 34.1 & 28.2 & 1.2 & 2.4 & 1.2 \\
\multicolumn{2}{l}{ June to September POD $\left.(\mathrm{mmol} \mathrm{m})^{-2}\right)$} & \multicolumn{2}{l}{ June to } & September POD6 $\left(\mathrm{mmol} \mathrm{m}^{-2}\right)$ \\
Field & WRF-CHIMERE & QQ Trans & Field & WFR-CHIMERE & QQ Trans \\
17.8 & 23.3 & 19.6 & 0.4 & 1.8 & 1.0 \\
\hline
\end{tabular}

mmol $\mathrm{m}^{-2}$. If we were to rely on the POD6 derived from the WRF-CHIMERE simulations $\left(2.4 \mathrm{mmol} \mathrm{m}^{-2}\right)$ as calculated here without any other adjustment, the grapevine $\mathrm{Cl}_{\text {ef }}$ value for $10 \%$ reduction in monosaccharide concentrations would also be reached for the non-consecutive case $\left(2.3 \mathrm{mmol} \mathrm{m}^{-2}\right)$ besides that for yield over consecutive years $\left(2.2 \mathrm{mmol} \mathrm{m}^{-2}\right)$. The modelled values of grapevine stomatal flux were in the range $100-250 \mathrm{mmol} \mathrm{H}_{2} \mathrm{O} \mathrm{m}^{-2} \mathrm{~s}^{-1}$ (Barreales et al., 2018; Ribeiro et al., 2018) also corresponding to those of autochthonous grapevine cultivars present in the study area (e.g. 'Touriga Franca' and 'Touriga Nacional) when there is not severe water stress condition.

The associated QQ transformed POD and POD6 maps (Fig. 5a and b) were also related with elevation showing a higher biological control where warmer and drier areas have lower stomatal fluxes. The Apr-Sep POD6 adjusted map (Fig. 5b) showed that considerable extensions of the 
DDR can exceed critical values for grapevine yield and quality, especially in the central and eastern part of the DDR. These results clearly manifested the relevance of performing suitable modelling validation and parametrization in order to increase the accuracy of ambient $\mathrm{O}_{3}$ risk assessments for agriculture, especially for the grapevine case where there is still much uncertainty and lack of experimental work. A significant difference was found between the field-based and the WRFCHIMERE based POD data distribution (KS test $\mathrm{p}<0.05$ ) (Fig. 5c) along uneven SDs ratios (Fig. 5d) which were corrected after QQ transformation (Fig. 5e and f).

\section{4. $\mathrm{O}_{3}$ phytotoxic risk per phenological stage}

Phenological observations are also important to appropriately assess risk. Fig. 6 displays $\mathrm{O}_{3}$ exposure per grapevine phenological stage (a), the age parameter that was specifically introduced into the used DO3SE deposition model (b), and variation of vegetation protection standards according to length of selected growing season $(c, d)$.

It can be observed that in Quinta da Leda the $\mathrm{O}_{3} 40$-ppb threshold was exceeded for all growth stages (Fig. 6a) reaching high values in rather sensitive stages, such as flowering, which in a perennial crop such as the grapevine, influences the development of the next growing season also affecting yield and quality. In fact, climate extremes in relation to early heatwaves in spring and accumulated hydric stress through the rest of the growing season in 2017 were reported to have had an effect in

$\mathrm{O}_{3}$ exposure per phenological stage

a)

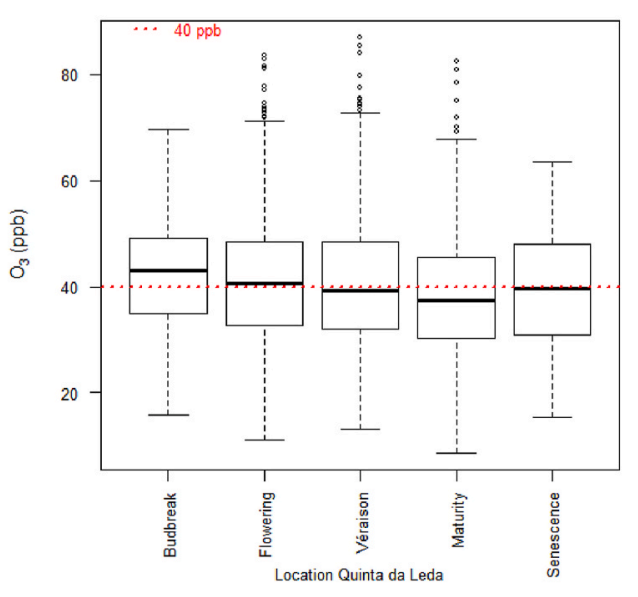

Field versus WRF-ERA-CHIMERE AOT40 estimates

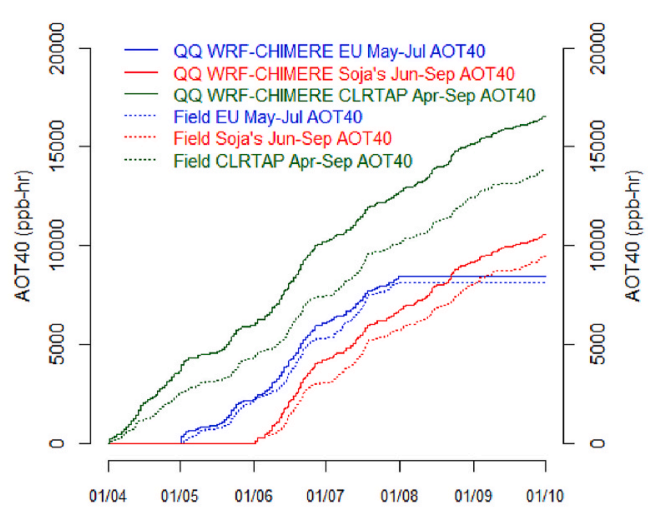

c)

Location Quinta da Leda the DDR on grapevine vegetative growth and yield (i.e. reduction in berry weight), although the sugar and phenolic compound levels were considered good (Associação para o Desenvolvemento da Viticultura Duriense, 2017). The availability of phenological observations for the 2017 campaign also allowed to define a specific growth stage parameter (Fig. 6b) to modify stomatal conductance better representing when grapevine leaves are fully developed besides timing of sensitive stages (i. e. flowering) in relation to $\mathrm{O}_{3}$ exposure in the DDR.

The estimation of both exposure (Fig. 6c) and stomatal uptake standards (Fig. 6d) for assessment of $\mathrm{O}_{3}$ phytotoxic risk on grapevine yield and quality was still subjected to a great range of variation depending on the length of the cumulative period selected to estimate those standards. It can be observed that even when the QQ transformed WRF-CHIMERE simulation-based AOT40 values were closer to measurement-based values, there was still a tendency to overestimate them, especially through the longer Apr-Sep observational period. However, adjusted modelling results were very good for both Apr-Sep and June-Sep POD and for Apr-Sep POD6, although there is still a great amount of overestimation for June-Sep POD6.

\section{Discussion}

Even though the magnitude and the different signs of the errors in RCM can at times compensate and be within an acceptable range for purposes such as water balance computation (e.g. Boulard et al., 2016),

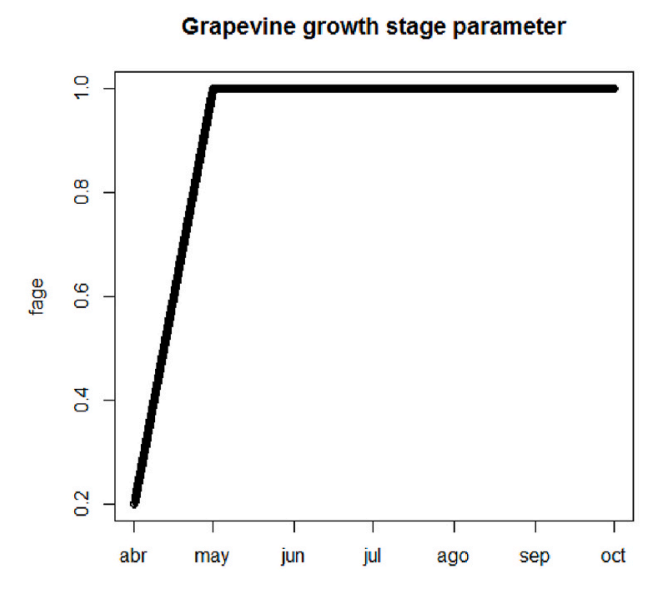

b)

\section{Field versus WRF-ERA-CHIMERE POD estimates}

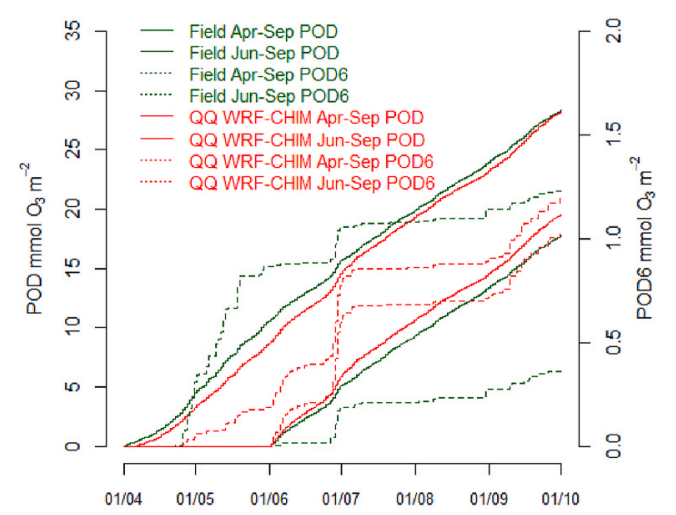

d)

Fig. 6. a) Possible critical periods according to phenological phase, b) plant growth parameter derived from phenological observations, and variation of c) exposure and d) dose-based vegetation protection standards according to length of selected growing season. 
it has been found in this work that these errors can have an effect on ambient $\mathrm{O}_{3}$ simulations inducing a relevant bias, which, in turn, can yield to an overestimation of cumulative standards for vegetation protection if no statistical transformation is used to match them with observational values. Another but not less relevant issue that relates with simulation bias has to do with the representativeness of emission inventories and their disaggregation methods. In this context, statistical transformations are a suitable postprocessing tool to reproduce more reliable estimates at local level.

Concerning POD estimation, it is also advisable to check that stomatal conductance values are in range with values measured in the field. This was possible for this study as they were also measured across the DDR during the field campaign, in particular along the veraison and maturity stages. Further work still needs to be done to better accommodate the model to the more severe water stress conditions that can be associated to non or controlled irrigated conditions, especially in the drier Cima Corgo and Douro Superior subregions. This could be done by effectively introducing a soil water balance parameter into the DO3SE model. There has not been a specific parametrization concerning the local varieties grown in the area either, excepting the plant growth (phenological) stage parameter. Despite those limitations, simulated values of stomatal conductance were representative of the less water stressed conditions in the DDR. Therefore, probably the Cima Corgo and Douro Superior subregions present larger areas that could exceed POD standards, as stomatal closure could exert a greater control to $\mathrm{O}_{3}$ entering the grapevine under the more severe water stress conditions of these regions. However, it must also be kept in mind that there is little knowledge on possible interaction of $\mathrm{O}_{3}$ with other concurrent environmental factors such as severe summer water deficit, heat waves, or strong light conditions which could also affect plant defense mechanisms.

\section{Conclusions}

The results of this work stress the relevance of performing modelling validation in order to increase the accuracy of high-resolution ambient $\mathrm{O}_{3}$ risk assessments for agriculture, especially for a case such as grapevine, where there is still much uncertainty due to the lack of experimental work. This is particularly important due to the grapevine production immense value for social, economic and environmental sustainability in Mediterranean areas and beyond. Both field and statistically adjusted model values indicate that considerable areas in the Demarcated Douro Region of Portugal exceed the critical exposure values for vegetation according to current European legislation standards, and for grapevine yield and quality criteria based on current OTC experimental knowledge. The simulations already included a plant growth stage parameter taking into account grapevine phenological observations in the study area, but further work is still required to better represent the more water stressed conditions in the study area, as a soil water limiting factor has not yet been effectively included into the DO3SE model. These results also indicate the need for rethinking airquality standards under the potential impacts of climate change and extreme climate events when assessing the ozone risk for strategic crops in Mediterranean areas, such as the grapevine.

\section{CRediT authorship contribution statement}

D. Blanco-Ward: Conceptualization, Methodology, WRF-CHIMERE simulations and postprocessing, field campaign data postprocessing, Writing - original draft, Writing - review \& editingWriting- Reviewing and Editing. A. Rocha: WRF simulations, manuscript reviewing. C. Viceto: WRF simulations, manuscript reviewing. A.C. Ribeiro: Field campaign data collection and manuscript reviewing. M. Feliciano: Field campaign data collection and manuscript reviewing. E. Paoletti: Conceptualization, Supervision. A.I. Miranda: Conceptualization, Supervision.

\section{Declaration of competing interest}

The authors declare that they have no known competing financial interests or personal relationships that could have appeared to influence the work reported in this paper.

\section{Acknowledgements}

The authors acknowledge the national funds from FCT-Science and Technology Portuguese Foundation for the doctoral grant of D. BlancoWard (SFRH/BD/139193/2018). Thanks are also due for the financial support to CESAM (UIDB/50017/2020+UIDP/50017/2020), to FCT/ MEC through national funds, and the co-funding by FEDER within the PT2020 Partnership Agreement and Compete 2020. The authors also wish to thank the DOUROZONE project (PTDC/AAG-MAA/3335/2014; POCI-01-0145-FEDER-016778) for financial support through Project 3599 - Promoting the Scientific Production and the Technological Development, and Thematic Networks (3599-PPCDT) - and through FEDER. Thanks are also given to SOGRAPE VINHOS S.A. for facilitating the collection of surface $\mathrm{O}_{3}$ data and sharing meteorological data at one of their vineyard fields.

\section{Appendix A. Supplementary data}

Supplementary data to this article can be found online at https://doi. org/10.1016/j.atmosenv.2021.118507.

\section{References}

Agência Portuguesa do Ambiente, 2009. Avaliação dos Níveis de Ozono no Ar Ambiente em Portugal. Amadora.

Agência Portuguesa do Ambiente, 2011. Avaliação dos Níveis de Ozono no Ar Ambiente em Portugal. Amadora.

Ainsworth, E., Yendrek, C.R., Sitch, S., Collins, W.J., Emberson, L.D., 2012. The effects of tropospheric ozone on net primary productivity and implications for climate change. Annu. Rev. Plant Biol. 63 (March), 637-661. https://doi.org/10.1146/annurevarplant-042110-103829.

Associação para o Desenvolvemento da Viticultura Duriense, 2017. Ano Vitícola 2017. Balanço Final. Boletim 14-17. Vila Real.

Avnery, S., Mauzerall, D.L., Liu, J., Horowitz, L.W., 2011. Global crop yield reductions due to surface ozone exposure: 2. Year 2030 potential crop production losses and economic damage under two scenarios of 03 pollution. Atmos. Environ. 45 (13), 2297-2309. https://doi.org/10.1016/j.atmosenv.2011.01.002.

Barreales, D., Verdial, J., Feliciano, M., Castro, J., Rodrigues, M., Blanco-ward, D., Ribeiro, A.C., 2018. Efecto del riego deficitario en los cultivares Touriga Nacional y Touriga Franca ( Vitis vinifera L .) en la Región Demarcada del Duero ( Portugal ). In: Effect of Deficit Irrigation in the Cultivars Touriga Nacional and Touriga Franca ( Vitis vinifera L .) I. XIIth International Terroir Congress. Zaragoza, 18th-22nd of June 2018.

Blanco-Ward, D., Ribeiro, A., Paoletti, E., Miranda, A., 2021. Assessment of tropospheric ozone phytotoxic effects on the grapevine (Vitis vinifera L.): a review. Atmos. Environ. 244 (11 09 2020) https://doi.org/10.1016/j.atmosenv.2020.117924.

Blanco-Ward, D., Monteiro, A., Lopes, M., Borrego, C., Silveira, C., Viceto, C., Rocha, A., Ribeiro, A., Andrade, J., Feliciano, M., Castro, J., Barreales, D., Neto, J., Carlos, C., Peixoto, C., Miranda, A., 2019. Climate change impact on a wine-producing region using a dynamical downscaling approach: climate parameters, bioclimatic indices and extreme indices. Int. J. Climatol. joc 6185. https://doi.org/10.1002/joc.6185.

Booker, F., Muntifering, R., McGrath, M., Burkey, K., Decoteau, D., Fiscus, E., Manning, W., Krupa, S., Chappelka, A., Grantz, D., 2009. The ozone component of global change: potential effects on agricultural and horticultural plant yield, product quality and interactions with invasive species. J. Integr. Plant Biol. Blackwell Publ. Asia 51 (4), 337-351. https://doi.org/10.1111/j.1744-7909.2008.00805.x.

Borrego, C., Monteiro, A., Ferreira, J., Miranda, A.I., Costa, A.M., Carvalho, A.C., Lopes, M., 2008. Procedures for estimation of modelling uncertainty in air quality assessment. Environ. Int. 34 (5), 613-620. https://doi.org/10.1016/j envint.2007.12.005.

Boulard, D., Castel, T., Camberlin, P., Sergent, A.-S., Bréda, N., Badeau, V., Rossi, A., Pohl, B., 2016. Capability of a regional climate model to simulate climate variables requested for water balance computation: a case study over northeastern France. Clim. Dynam. 46, 2689-2716. https://doi.org/10.1007/s00382-015-2724-9.

Carvalho, A., Monteiro, A., Ribeiro, I., Tchepel, O., Miranda, A.I., Borrego, C., Saavedra, S., Souto, J.A., Casares, J.J., 2010. High ozone levels in the northeast of Portugal: analysis and characterization. Atmos. Environ. 44 (8), 1020-1031. https:// doi.org/10.1016/j.atmosenv. 2009.12.020.

Carvalho, D., Rocha, A., Gómez-Gesteira, M., Santos, C., 2012. A sensitivity study of the WRF model in wind simulation for an area of high wind energy. In: Environmental 
Modelling and Software. Elsevier 33, pp. 23-34. https://doi.org/10.1016/j. envsoft.2012.01.019.

CLRTAP, 2017a. Supplement of chapter III (mapping critical levels for vegetation). Manual on methodologies and criteria for modelling and mapping critical loads and levels and air pollution effects. Risks and Trends 1-60. Bangor.

CLRTAP, 2017b. Mapping critical levels for vegetation, chapter III. Manual on Methodologies and Criteria for Modelling and mapping critical Loads and Levels and air pollution effects. Risks Trends 1-66. Bangor.

CLRTAP, 2017c. Developing Areas of Research of Relevance to Chapter III (Mapping Critical Levels for Vegetation) of the Modelling and Mapping Manual of the LRTAP Convention. Scientific background document B, Bangor.

Emberson, L.D., Ashmore, M.R., Cambridge, H.M., Simpson, D., Tuovinen, J.-P., 2000a Modelling stomatal ozone flux across Europe. Environ. Pollut. 109 (3), 403-413. https://doi.org/10.1016/S0269-7491(00)00043-9.

Emberson, L.D., Massman, W.J., Büker, P., Soja, G., Van De Sand, I., Mills, G., Jacobss, C., 2005. The development, evaluation and application of O3 flux and flux-response models for additional agricultural crops. In: Wieser, G.M.T. (Ed.), Proceedings on the Workshop "Critical Levels of Ozone: Further Applying and Developing the FluxBased Concept. " Obergurgl, pp. 220-225.

Emberson, L.D., Simpson, D., Tuovinen, J.-P., Ashmore, M.R., Cambridge, H.M., 2000b. Towards a Model of Ozone Deposition and Stomatal Uptake over Europe. Norwegian Meteorological Institute, Oslo.

Emery, C., Liu, Z., Russell, A.G., Odman, M.T., Yarwood, G., Kumar, N., 2017. Recommendations on statistics and benchmarks to assess photochemical model performance. J. Air Waste Manag. Assoc. Taylor Francis 67 (5), 582-598. https:// doi.org/10.1080/10962247.2016.1265027.

Feng, Z., De Marco, A., Anav, A., Gualtieri, M., Sicard, P., Tian, H., Fornasier, F., Tao, F., Guo, A., Paoletti, E., 2019. Economic Losses Due to Ozone Impacts on Human Health, Forest Productivity and Crop Yield across China. Environment International, vol. 131. Elsevier, p. 104966. https://doi.org/10.1016/j.envint.2019.104966. July.

Fortems-Cheiney, A., Foret, G., Siour, G., Vautard, R., Szopa, S., Dufour, G., Colette, A., Lacressonniere, G., Beekmann, M., 2017. A $3{ }^{\circ} \mathrm{C}$ global RCP8.5 emission trajectory cancels benefits of European emission reductions on air quality. Nature Communications. Nat. Publ. Group 8 (1), 89. https://doi.org/10.1038/s41467-01700075-9.

Fraga, H., García de Cortázar Atauri, I., Malheiro, A.C., Santos, J.A., 2016. Modelling Climate Change Impacts on Viticultural Yield, Phenology and Stress Conditions in Europe. Global Change Biology, vol. 22. John Wiley \& Sons, Ltd (10.1111), pp. 3774-3788. https://doi.org/10.1111/gcb.13382, 11.

Gudmundsson, L., Bremnes, J.B., Haugen, J.E., Engen-Skaugen, T., 2012. Technical Note: downscaling RCM precipitation to the station scale using statistical transformations a comparison of methods. Hydrol. Earth Syst. Sci. 16 (9), 3383-3390. https://doi. org/10.5194/hess-16-3383-2012.

Instituto dos Vinhos do Douro e Porto, 2017. Areas dedicated to grapevine cultivation. Stat. Year 2016.

Jacob, D.J., Winner, D.A., 2009. Effect of climate change on air quality. Atmos. Environ. 43, 51-63. https://doi.org/10.1016/j.atmosenv.2008.09.051.

Jiménez, P.A., Dudhia, J., González-Rouco, J.F., Montávez, J.P., García-Bustamante, E., Navarro, J., Vilà-Guerau De Arellano, J., Muñoz-Roldán, A., 2013. An evaluation of WRF's ability to reproduce the surface wind over complex terrain based on typical circulation patterns. J. Geophys. Resear. Atmos. 118 (14), 7651-7669. https://doi. org/10.1002/jgrd.50585.

Jones, G.V., Alves, F., 2012. Impact of climate change on wine production: a global overview and regional assessment in the Douro Valley of Portugal. Int. J. Glob. Warming 4 (3/4), 383-406.

Katragkou, E., Zanis, P., Kioutsioukis, I., Tegoulias, I., Melas, D., Krüger, B.C., Coppola, E., 2011. Future climate change impacts on summer surface ozone from regional climate-air quality simulations over Europe. J. Geophys. Res.: Atmos. 116 (D22307), 1-14. https://doi.org/10.1029/2011JD015899.

Kryza, M., Wałaszek, K., Ojrzyńska, H., Szymanowski, M., Werner, M., Dore, A.J., 2017. High-resolution dynamical downscaling of ERA-interim using the WRF regional climate model for the area of Poland. Part 1: model configuration and statistical evaluation for the 1981-2010 period. Pure Appl. Geophys. 174 (2), 511-526. https://doi.org/10.1007/s00024-016-1272-5.

Li, P., Feng, Z., Catalayud, V., Yuan, X., Xu, Y., Paoletti, E., 2017. A Meta-Analysis on Growth, Physiological, and Biochemical Responses of Woody Species to GroundLevel Ozone Highlights the Role of Plant Functional Types. Plant, Cell \& Environment, vol. 40. John Wiley \& Sons, Ltd (10.1111), pp. 2369-2380. https:// doi.org/10.1111/pce.13043, 10.

López, J., Troncoso, F., Granada, E., Eguía, P., 2020. Comparison between Geostatistical Interpolation and Numerical Weather Model Predictions for Meteorological Conditions Mapping. Infrastructures, vol. 5. Multidisciplinary Digital Publishing Institute, p. 15. https://doi.org/10.3390/infrastructures5020015, 2.

Lorente-Plazas, R., Montávez, J.P., Jimenez, P.A., Jerez, S., Gómez-Navarro, J.J., GarcíaValero, J.A., Jimenez-Guerrero, P., 2015. Characterization of Surface Winds over the Iberian Peninsula. International Journal of Climatology, vol. 35. John Wiley and Sons Ltd, pp. 1007-1026. https://doi.org/10.1002/joc.4034, 6.

Mailler, S., Menut, L., Khvorostyanov, D., Valari, M., Couvidat, F., Siour, G., Turquety, S., Briant, R., Tuccella, P., Bessagnet, B., Colette, A., Létinois, L., Meleux, F., Mailler, S., 2016. CHIMERE-2016: from urban to hemispheric chemistry-transport modeling. Geosci. Model Dev. (GMD). https://doi.org/10.5194/gmd-2016-196.

Marta-Almeida, M., Teixeira, J., Carvalho, M.J., Melo-Gonçalves, P., Rocha, A.M., 2016. High resolution WRF climatic simulations for the Iberian Peninsula: model validation. Phys. Chem. Earth 94, 94-105. https://doi.org/10.1016/j. pce.2016.03.010.
Massman, W.J., 2004. Toward an ozone standard to protect vegetation based on effective dose: a review of deposition resistances and a possible metric. Atmos. Environ. 38 (15), 2323-2337. https://doi.org/10.1016/j.atmosenv.2003.09.079.

Mauzerall, D.L., Wang, X., 2001. Protecting agricultural crops from the effects of tropospheric ozone exposure. Annu. Rev. Energy Environ. 26, 237-268.

Meleux, F., Solmon, F., Giorgi, F., 2007. Increase in summer European ozone amounts due to climate change. Atmos. Environ. 41 (35), 7577-7587. https://doi.org/ 10.1016/j.atmosenv.2007.05.048.

Menut, L., Bessagnet, B., Khvorostyanov, D., Beekmann, M., Blond, N., Colette, A., Coll, I., Curci, G., Foret, G., Hodzic, A., Mailler, S., Meleux, F., Monge, J.-L., Pison, I., Siour, G., Turquety, S., Valari, M., Vautard, R., Vivanco, M.G., 2013. Chimere 2013: a model for regional atmospheric composition modelling. Geosci. Model Dev. (GMD) 6 (4), 981-1028. https://doi.org/10.5194/gmd-6-981-2013.

Mills, G., Harmens, H., Hayes, F., Jones, L., Williams, P., Emberson, L., Cinderby, S., Terry, A., Ashmore, M., Holland, M., Ge and Ps, 2006. The UNECE International Cooperative Programme on Vegetation Final Report.

Mills, G., Pleijel, H., Braun, S., Büker, P., Bermejo, V., Calvo, E., Danielsson, H., Emberson, L., Fernández, I.G., Grünhage, L., Harmens, H., Hayes, F., Karlsson, P.-E., Simpson, D., 2011. New stomatal flux-based critical levels for ozone effects on vegetation. Atmos. Environ. https://doi.org/10.1016/j.atmosenv.2011.06.009.

Mills, G., Pleijel, H., Malley, C.S., Sinha, B., Cooper, O.R., Schultz, M.G., Neufeld, H.S., Simpson, D., Sharps, K., Feng, Z., Gerosa, G., Harmens, H., Kobayashi, K., Saxena, P., Paoletti, E., Sinha, V., Xu, X., 2018. Tropospheric Ozone Assessment Report: presentday tropospheric ozone distribution and trends relevant to vegetation. Elementa 6 (47). https://doi.org/10.1525/elementa.273.

Mira de Orduña, R., 2010. Climate change associated effects on grape and wine quality and production. Food Res. Int. 43, 1844-1855. https://doi.org/10.1016/j foodres.2010.05.001.

Miranda, A.I., Ascenso, A., Gama, C., Blanco-ward, D., Silveira, C., Viceto, C., Rocha, A., Lopes, D., Borrego, C., 2020. Ozone risk for Douro vineyards in present and future climates. In: Mensink, C., Gong, W., Hakami, A. (Eds.), Air Pollution Modeling and its Application XXVI, 36th International Technical Meeting on Air Pollution Modeling and its Application, Canada, May 14-18, 2018. Springer.

Monteiro, A., Strunk, A., Carvalho, A., Tchepel, O., Miranda, A.I., Borrego, C., Saavedra, S., Rodríguez, A., Souto, J., Casares, J., Friese, E., Elbern, H., 2012. Investigating a high ozone episode in a rural mountain site. Environ. Pollut. 162, 176-189. https://doi.org/10.1016/j.envpol.2011.11.008.

Musselman, R.C., Lefohn, A.S., Massman, W.J., Heath, R.L., 2006. A critical review and analysis of the use of exposure-and flux-based ozone indices for predicting vegetation effects. Atmos. Environ. 40, 1869-1888. https://doi.org/10.1016/j. atmosenv.2005.10.064.

Oltmans, S.J., Lefohn, A.S., Shadwick, D., Harris, J.M., Scheel, H.E., Galbally, I., Tarasick, D.W., Johnson, B.J., Brunke, E.G., Claude, H., Zeng, G., Nichol, S., Schmidlin, F., Davies, J., Cuevas, E., Redondas, A., Naoe, H., Nakano, T. Kawasato, T., 2013. Recent tropospheric ozone changes - a pattern dominated by slow or no growth. Atmos. Environ. 67 https://doi.org/10.1016/j. atmosenv. 2012.10.057.

Pan, L., Liu, Y., Knievel, J., Delle Monache, L., Roux, G., 2018. Evaluations of WRF sensitivities in surface simulations with an ensemble prediction system. Atmosphere. MDPI AG 9 (3), 106. https://doi.org/10.3390/atmos9030106.

Pan, X., Li, X., 2011. Validation of WRF model on simulating forcing data for Heihe River Basin. Sci. Cold Arid Reg. 3 (4), 344-357. https://doi.org/10.3724/SP. J.1226.2011.00344.

Paoletti, E., De Marco, A., Beddows, D.C.S., Harrison, R.M., Manning, W.J., 2014. Ozone levels in European and USA cities are increasing more than at rural sites, while peak values are decreasing. Environ. Pollut. 192, 295-299. https://doi.org/10.1016/j. envpol.2014.04.040.

Paoletti, E., Manning, W.J., 2007. Toward a biologically significant and useable standard for ozone that will also protect plants. Environ. Pollut. 150 (1), 85-95. https://doi. org/10.1016/j.envpol.2007.06.037.

Pellegrini, E., Campanella, A., Paolocci, M., Trivellini, A., Gennai, C., Muganu, M., Nali, C., Lorenzini, G., 2015. Functional leaf traits and diurnal dynamics of photosynthetic parameters predict the behavior of grapevine varieties towards ozone. Plos One. Public Libr. Sci. 10 (8) https://doi.org/10.1371/journal. pone. 0135056

Perdigão, J., Salgado, R., Magarreiro, C., Soares, P.M.M., João Costa, M., Dasari, H.P., 2017. An Iberian climatology of solar radiation obtained from WRF regional climate simulations for 1950-2010 period. Atmos. Res. 198, 151-162. https://doi.org/ 10.1016/j.atmosres.2017.08.016.

Pires, J.C.M., Alvim-Ferraz, M.C.M., Martins, F.G., 2012. Surface ozone behaviour at rural sites in Portugal. Atmos. Res. 104, 164-171. https://doi.org/10.1016/j. atmosres.2011.10.001.

Politi, N., Nastos, P.T., Sfetsos, A., Vlachogiannis, D., Dalezios, N.R., Gounaris, N., Cardoso, M.R., Soares, M.M.P., 2017. Comparison and Validation of WRF Model Physics Parameterizations over the Domain of Greece. Perspectives on Atmospheric Sciences. Springer, Cham, pp. 55-61. https://doi.org/10.1007/978-3-319-35095-0 8.

Ponti, L., Gutierrez, A.P., Boggia, A., Neteler, M., 2018. Analysis of grape production in the face of climate change. Climate 6 (2), 1-15. https://doi.org/10.3390/ cli6020020.

Ribeiro, A.C., Barreales, D., Andrade, J., Rodrigues, M.A., Blanco-ward, D., Monteiro, A., Lopes, M., Borrego, C., Silveira, C., Viceto, C., Feliciano, M., Castro, J., Miranda, A., 2018. Physiological response of the grapevine cultivars Touriga Nacional and Touriga Franca to increasing summer stress conditions in the Douro. In: XIIth International Terroir Congress, Zaragoza, 18th-22nd of June 2018, p. 4. 
Ribeiro, J.A., 2000. Caracterização genérica da região vinhateira do Alto Douro. Douro Estudos \& Documentos, pp. 11-29.

Richards, B.L., Middleton, J.T., Hewitt, W.B., 1959. Ozone Stipple of Grape Leaf, December 1959. California Agriculture, pp. 4-11.

Sicard, P., Anav, A., De Marco, A., Paoletti, E., 2017. Supplement of projected global ground-level ozone impacts on vegetation under different emission and climate scenarios. Atmos. Chem. Phys. 17 (19), 12177-12196. https://doi.org/10.5194/acp17-12177-2017.

Sicard, P., De Marco, A., Troussier, F., Renou, C., Vas, N., Paoletti, E., 2013. Decrease in surface ozone concentrations at Mediterranean remote sites and increase in the cities. Atmos. Environ. 79, 705-715. https://doi.org/10.1016/j. atmosenv.2013.07.042.

Skamarock, W.C., Klemp, J.B., Dudhi, J., Gill, D.O., Barker, D.M., Duda, M.G., Huang, X.Y., Wang, W., Powers, J.G., 2008. A Description of the Advanced Research WRF Version 3. National Center for Atmospheric Research (NACR) Technical Note, Boulder, Colorado. https://doi.org/10.5065/D6DZ069T.

Soares, P.M.M., Cardoso, R.M., Pedro, Miranda, M.A., De Medeiros, J., Belo-Pereira, M., Espirito-Santo, F., 2012. WRF high resolution dynamical downscaling of ERAInterim for Portugal. Clim. Dynam. 39, 2497-2522. https://doi.org/10.1007/ s00382-012-1315-2.

Soja, G., Eid, M., Gangl, H., Redl, H., 1997. Ozone sensitivity of grapevine (Vitis vinifera L.): evidence for a memory effect in a perennial crop plant? Phyton 37 (3), 265-270.

Soja, G., Reichenauer, T.G., Eid, M., Soja, A.-M., Schaber, R., Gangl, H., 2004. Long-term ozone exposure and ozone uptake of grapevines in open-top chambers. Atmos. Environ. 38, 2313-2321. https://doi.org/10.1016/j.atmosenv.2003.12.038.

Sousa, S.I.V., Alvim-Ferraz, M.C.M., Martins, F.G., 2011. Identification and origin of nocturnal ozone maxima at urban and rural areas of Northern Portugal - influence of horizontal transport. Atmos. Environ. 45 (4), 942-956. https://doi.org/10.1016/j. atmosenv.2010.11.008.

The Royal Society, 2008. Ground-level Ozone in the 21st Century: Future Trends, Impacts and Policy Implications. Science Policy Report, 15/08 (London).

Tonietto, J., Carbonneau, A., 2004. A multicriteria climatic classification system for grape-growing regions worldwide. Agric. For. Meteorol. 124, 81-97. https://doi. org/10.1016/j.agrformet.2003.06.001.

Valletta, A., Salvatori, E., Rita Santamaria, A., Nicoletti, M., Toniolo, C., Caboni, E., Bernardini, A., Pasqua, G., Manes, F., 2016. Ecophysiological and phytochemical response to ozone of wine grape cultivars of Vitis vinifera L. Nat. Prod. Resear. Taylor \& Francis 30 (22), 2514-2522. https://doi.org/10.1080/ 14786419.2015.1118631.

Van Dingenen, R., Dentener, F.J., Raes, F., Krol, M.C., Emberson, L., Cofala, J., 2009. The global impact of ozone on agricultural crop yields under current and future air quality legislation. Atmos. Environ. 43 (3), 604-618. https://doi.org/10.1016/j. atmosenv.2008.10.033.

Van Leeuwen, C., Darriet, P., 2016. The impact of climate change on viticulture and wine quality. J. Wine Econ. 11 (1), 150-167. https://doi.org/10.1017/jwe.2015.21.

Willmott, C.J., Robeson, S.M., Matsuura, K., 2012. A refined index of model performance. Int. J. Climatol. 32 (13), 2088-2094. https://doi.org/10.1002/ joc. 2419.

Zhang, H., Pu, Z., Zhang, X., 2013. Examination of errors in near-surface temperature and wind from WRF numerical simulations in regions of complex terrain. Weather Forecast. 28 (3), 893-914. https://doi.org/10.1175/WAF-D-12-00109.1.

Zittis, G., Hadjinicolaou, P., Lelieveld, J., 2014. Comparison of WRF model physics parameterizations over the MENA-CORDEX domain. Am. J. Clim. Change 490-511. https://doi.org/10.4236/ajcc.2014.35042, 03(05). 